\title{
The carbon balance of South America: a review of the status, decadal trends and main determinants
}

\author{
M. Gloor ${ }^{1}$, L. Gatti ${ }^{2}$, R. Brienen ${ }^{1}$, T. R. Feldpausch ${ }^{1}$, O. L. Phillips ${ }^{1}$, J. Miller ${ }^{3}$, J. P. Ometto ${ }^{4}$, H. Rocha ${ }^{5}$, T. Baker ${ }^{1}$, \\ B. de Jong ${ }^{18}$, R. A. Houghton ${ }^{7}$, Y. Malhi ${ }^{6}$, L. E. O. C. Aragão ${ }^{8}$, J.-L. Guyot ${ }^{9}$, K. Zhao ${ }^{10}$, R. Jackson $^{10}$, P. Peylin ${ }^{11}$, \\ S. Sitch ${ }^{13}$, B. Poulter ${ }^{12}$, M. Lomas ${ }^{14}$, S. Zaehle ${ }^{15}$, C. Huntingford ${ }^{16}$, P. Levy ${ }^{16}$, and J. Lloyd ${ }^{1,17}$ \\ ${ }^{1}$ University of Leeds, School of Geography, Woodhouse Lane, LS9 2JT, Leeds, UK \\ ${ }^{2}$ CNEN-IPEN-Lab., Quimica Atmosferica, Av. Prof. Lineu Prestes, 2242, Cidade Universitaria, Sao Paulo, Brazil \\ ${ }^{3}$ NOAA/ESRL R/GMD1 325 Broadway, Boulder, CO 80305, USA \\ ${ }^{4}$ Earth System Science Centre (CCST) National Institute for Space Research (INPE) Av. dos Astronautas, 1758 12227-010. \\ São Jose dos Campos, Brazil \\ ${ }^{5}$ Departamento de Ciências Atmosféricas/IAG/Universidade de São Paulo, Rua do Matão, 1226 - Cidade Universitária \\ - São Paulo, Brazil \\ ${ }^{6}$ University of Oxford, Environmental Change Institute, School of Geography and the Environment, South Parks Road, \\ Oxford OX1 3QY, UK \\ ${ }^{7}$ Woods Hole Research Center, 149 Woods Hole Road, Falmouth, MA 02540-1644, USA \\ ${ }^{8}$ School of Geography, University of Exeter, Amory Building (room 385), Rennes Drive, Devon, EX4 4RJ, UK \\ ${ }^{9}$ IRD, CP 7091 Lago Sul, 71635-971 Brasília DF, Brazil \\ ${ }^{10}$ Nicholas School of the Environment, Duke University, Box 90338/rm 3311 French FSC-124 Science Drive, Durham, \\ NC 27708-0338, USA \\ ${ }^{11}$ CEA centre de Saclay, Orme des Merisiers, LSCE, Point courrier 129, 91191 Gif Sur Yvette, France \\ ${ }^{12}$ Laboratoire des Sciences du Climat et l'Environnement (LSCE) Orme des Merisiers, Point courrier 129, \\ 91191 Gif Sur Yvette, France \\ ${ }^{13}$ College of Life and Environmental Sciences, University of Exeter, Rennes Drive, Exeter EX4 4RJ, UK \\ ${ }^{14}$ Centre for Terrestrial Carbon Dynamics CTCD, University of Sheffield, Hicks Building, Hounsfield Road, \\ Sheffield S3 7RH,UK \\ ${ }^{15}$ Max-Planck-Institute for Biogeochemistry- Biogeochemical Systems Department, P.O. Box 1001 64, D-07701 Jena, \\ Germany \\ ${ }^{16}$ Centre for Ecology and Hydrology, Bush Estate, Penicuik, Midlothian, EH26 0QB, UK \\ ${ }^{17}$ School of Earth and Environmental Studies, James Cook University, Cairns, Queensland 4878, Australia \\ ${ }^{18}$ El Colegio de la Frontera Sur (ECOSUR), Carr, Panamericana-Periferico Sur s/n, San Cristóbal de las Casas, \\ 29290 Chiapas, México
}

Correspondence to: M. Gloor (eugloor@googlemail.com)

Received: 30 November 2011 - Published in Biogeosciences Discuss.: 17 January 2012 Revised: 6 June 2012 - Accepted: 20 November 2012 - Published: 21 December 2012

\begin{abstract}
We summarise the contemporary carbon budget of South America and relate it to its dominant controls: population and economic growth, changes in land use practices and a changing atmospheric environment and climate. Component flux estimate methods we consider sufficiently reliable for this purpose encompass fossil fuel emission invento-
\end{abstract}

ries, biometric analysis of old-growth rainforests, estimation of carbon release associated with deforestation based on remote sensing and inventories, and agricultural export data. Alternative methods for the estimation of the continentalscale net land to atmosphere $\mathrm{CO}_{2}$ flux, such as atmospheric transport inverse modelling and terrestrial biosphere model 
predictions, are, we find, hampered by the data paucity, and improved parameterisation and validation exercises are required before reliable estimates can be obtained. From our analysis of available data, we suggest that South America was a net source to the atmosphere during the 1980s $(\sim 0.3-$ $\left.0.4 \mathrm{Pg} \mathrm{Ca}^{-1}\right)$ and close to neutral $\left(\sim 0.1 \mathrm{Pg} \mathrm{Ca}^{-1}\right)$ in the 1990s. During the latter period, carbon uptake in old-growth forests nearly compensated for the carbon release associated with fossil fuel burning and deforestation.

Annual mean precipitation over tropical South America as inferred from Amazon River discharge shows a long-term upward trend. Although, over the last decade dry seasons have tended to be drier, with the years 2005 and 2010 in particular experiencing strong droughts. On the other hand, precipitation during the wet seasons also shows an increasing trend. Air temperatures have also increased slightly. Also with increases in atmospheric $\mathrm{CO}_{2}$ concentrations, it is currently unclear what effect these climate changes are having on the forest carbon balance of the region. Current indications are that the forests of the Amazon Basin have acted as a substantial long-term carbon sink, but with the most recent measurements suggesting that this sink may be weakening. Economic development of the tropical regions of the continent is advancing steadily, with exports of agricultural products being an important driver and witnessing a strong upturn over the last decade.

\section{Introduction}

This review of the carbon balance of South America, with an emphasis on trends over the last few decades and their determinants, forms part of a catalogue of similar regional syntheses covering the globe as part of the RECCAP (REgional Carbon Cycle Assessment and Processes) effort. The scope of our analyses thus encompasses all methodologies as prescribed by RECCAP, including a "bottom-up" estimation of the net carbon balance through the assimilation of component flux measurements, simulations with Dynamic Global Vegetation Models (DGVMs) and atmospheric transport inversions.

South America as a region has attracted the attention of global carbon cycle and climate researchers mainly because of the very large amount of organic carbon stored in the forests of the Amazon Basin. Occupying just less than half the area of the continent, these forests have been estimated to contain around $95-120 \mathrm{Pg} \mathrm{C}$ in living biomass and an additional $160 \mathrm{Pg}$ C in soils (Gibbs et al., 2007; Malhi et al., 2006; Saatchi et al., 2011; Baccini et al., 2012; Jobaggy and Jackson, 2000; Table 1). Placing this in context, this ecosystem carbon stock (plants + soil) amounts to approximately half of the amount of carbon contained in the global atmosphere before the onset of the industrialisation in the 18th century. Thus, even if only a small fraction of this carbon pool were to be released to the atmosphere over coming decades and/or centuries as a consequence of land use change or biome shifts associated with a hotter/drier climate, then the implications for the global carbon budget (and climate change itself) would be significant. On the other hand, because of their vast area, high rates of productivity and reasonably long carbon residence times, these forests also have the potential to help moderate the global carbon problem through a growth stimulation in response to continually increasing $\left[\mathrm{CO}_{2}\right]$, thereby mitigating the effects of some fossil fuel burning emissions (Lloyd and Farquhar, 1996; Phillips et al., 1998). Nevertheless, this effect must eventually saturate (Lloyd and Farquhar, 2008), and hence two main factors will likely dictate future changes in forest biomass. First and of primary importance is the way in which the current fast demographic and economic development (e.g. Soares-Filho et al., 2006) will impact on all ecosystems of the region. Second, changes in ecosystem carbon densities in response to changes in atmospheric gas composition and climate (e.g. Phillips et al., 2009), perhaps also in conjunction with biome boundary shifts (e.g. Marimon et al., 2006), may also be of considerable consequence.

The continuing development of the Amazon Basin is associated directly with forest destruction mainly for agricultural use (e.g. DeFries et al., 2010). Changes brought about by altered climate and atmospheric composition on forests are subtler. Specifically, increases in carbon dioxide concentration and/or changes in direct light may stimulate tree growth and in turn rainforest biomass gains (Lloyd and Farquhar, 1996, 2008; Mercado et al., 2009), and there is strong evidence for such a process having occurred over the last few decades and to be still on-going (Phillips et al., 1998, 2009; Lewis et al., 2009). By contrast, a changing climate has, on the whole, been argued to be likely to have adverse effects on the tropical forests of the region. As for other parts of the globe, warming of the Earth's surface is predicted to result in an increase in climate variation in South America (Held and Soden, 2006), and this includes a likely increased frequency and intensity of unusually dry periods. Such increased variation, together with a general global warming, has the possibility to lead to forest decline through enhanced water stress. Drought induced forest loss may also be further amplified by fire (White et al., 1999; Cox et al., 2000; Poulter et al., 2010; Nepstad et al., 1999; Aragão and Shimabukuro, 2010). Altogether, it is the interplay between the very large area covered by high carbon density and relatively undisturbed forests with the very fast economic and demographic development, and these interacting with a changing climate, which makes South America of particular interest for its role in the contemporary carbon cycle and, in turn, to the climate of the planet over the decades to come.

This study aims to provide a state of the art assessment of the current day net carbon balance of South America through a review of carbon stocks and fluxes, their time trends, and their dominant controls. In doing this, we also describe how 
Table 1. Carbon stocks.

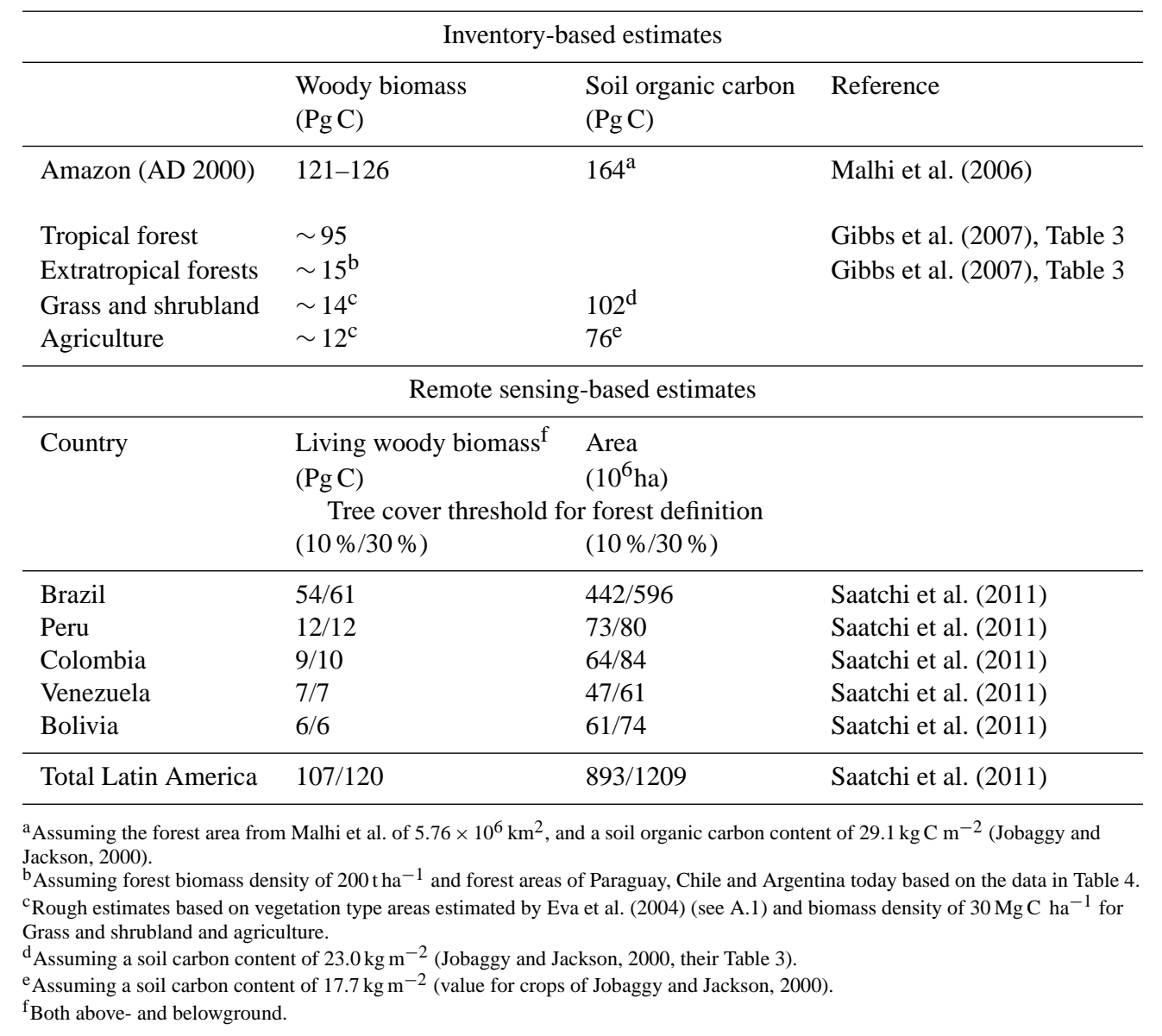

the carbon balance of South America has changed over recent decades and also provide an indication of what to expect in decades to come.

In order to quantify the continent's net carbon balance, we have adopted an "atmospheric" perspective. This can most easily be envisioned as a consideration of all fluxes across an imaginary vertical wall all around the continent's margin. Any carbon leaving the box enclosed by these walls (which is also imagined to have an infinite height) is a net carbon loss for South America (and a carbon source for the atmosphere), and vice versa. From this perspective, any internal transfers within the box - for example, the flow of detritus to rivers and/or its subsequent release as respired $\mathrm{CO}_{2}$ - is "carbon neutral" and thus does not need accounting. Similarly, although savanna fires may release substantial amounts of carbon to the atmosphere each year (van der Werf et al., 2010), only a fraction of the continental savanna area burns in each year, and the unburnt areas (almost all of which will be recovering from previous years' fires) accumulating biomass (Santos et al., 2004). Thus, as long as the total area of savanna (of any other vegetation type) remains unchanged, such "internal" fluxes can be ignored using our approach.
The paper is structured as follows. We start with a characterisation of main biomes, stocks, mean climate, climate trends, demography and economic development. We then present and discuss carbon fluxes associated with the different processes and estimate them using complementary methods. The dominant processes, considered in a loose sense, fall into the categories of fossil fuel emissions, deforestation, agriculture and trade, and forest biomass change. We then also discuss inferences from atmospheric greenhouse gas concentration data regarding the magnitude of carbon sources and sinks through atmospheric transport inverse modelling and dynamic vegetation model estimates.

\section{Main determinants of large-scale land surface changes and future energy consumption}

\subsection{Geography, population density, demography}

Of the South American nations, Brazil is geographically by far the largest, occupying $\sim 49 \%$ of the total area of $17.8 \times 10^{6} \mathrm{~km}^{2}$, followed by Argentina (16\%), Peru $(7 \%)$, Colombia (6\%) and Bolivia (6\%). Brazil is also the 
dominant economy of the continent, accounting for $\sim 50 \%$ of the continent's gross domestic product in 2009 and being the seventh largest in the world in terms of purchasing power parity (IMF, 2009).

The primary geographical pattern of the continent's population distribution (Fig. 1a) involves a band of very high density along the coastal arc stretching east and south from Venezuela, the Caribbean Sea and along the Pacific down to the South of Peru, and including the mega-cities Rio de Janeiro, São Paulo and Buenos Aires. This high population density along the coasts contrasts with the very low population density in the interior, especially within the still largely undeveloped Amazon Basin which covers an area of $\sim 8$ million $\mathrm{km}^{2}$ or nearly half the continent.

South America has witnessed very fast population growth, as well as increased urbanisation over the last 70 or so years (Fig. 2; Table 3). Rates of population growth remain substantial, but the continent-wide population is expected to stabilise at ca. 500 million inhabitants by around 2050 (Population Division of the Department of Economic and Social Affairs, UN, 2008).

In terms of "natural" ecosystem fluxes, one key region is the Amazon Basin, much of which remains covered by relatively undisturbed forest. Over half of the area of the Basin and its forest is located within Brazil (62\%), with the remaining $38 \%$ spread across nine countries of which the largest landholders are Peru (7\%), Bolivia (6\%), Colombia (6\%), and Venezuela $(6 \%)$. As well as hosting the largest contiguous tropical forest area in the world, the Amazon Basin also abounds with a massive but still relatively unexploited mineral and other natural resource wealth (e.g. Killeen, 2007a; Finer and Orta-Martinez, 2010). To date, however, development of the Basin has been mostly limited to a clearing of natural areas (of both forest and savanna) for cultivation and pasture. Improved access to global markets has played an important role in this development, especially over recent years (e.g. Nepstad et al., 2006a; DeFries, 2010, Butler and Laurance, 2008; Finer and Orta-Martinez, 2010).

\subsection{Biomes and their transformation over the last decades}

Based on the remote sensing estimates of Eva et al. (2004), the main vegetation and land cover types of South America include forest ( $45.2 \%$ by area, $\sim 8.04$ million $\mathrm{km}^{2}$ ), savanna and scrub lands $(25.1 \%)$ and agricultural land (24.1\%) (Table 2; Fig. 1b). These estimates refer to the time window of 1995-2000, with the remaining land covered by desert (Atacama, easternmost region of South America), water bodies and urban areas. Forest vegetation is predominantly located in the tropics, of which large parts are located within the Amazon Basin. Savanna type vegetation (the main belt to the south of the Amazon Basin generally being referred to as Cerrado in Brazil) originally stretched along a wide belt around the southern and eastern peripheries of the Amazon
Table 2. Vegetation cover of South America in $2000 \mathrm{AD}^{\mathrm{a}}$.

\begin{tabular}{|c|c|}
\hline Vegetation type & $\begin{array}{c}\text { Area } \\
\left(10^{6} \mathrm{~km}^{2}\right)\end{array}$ \\
\hline \multicolumn{2}{|l|}{ Natural vegetation } \\
\hline Humid tropical forest & 6.305 \\
\hline Dry tropical forest & 1.467 \\
\hline Temperate forests & 0.197 \\
\hline Grass and shrubland & 4.456 \\
\hline \multicolumn{2}{|l|}{ Agriculturally used land } \\
\hline Intensive agriculture & 2.025 \\
\hline Mosaic with degraded non-forest vegetation & 0.735 \\
\hline Mosaic with degraded forest vegetation & 1.513 \\
\hline
\end{tabular}

forest area (Eva et al., 2004), with coastal temperate forests to the east. Regions further south are used for agriculture, including sugar cane plantations in Sao Paulo state for the purpose of ethanol production and still further south for cattle grazing (southeastern Brazil and Argentina). Much of the latter area was originally "Atlantic forest", having been cleared many decades ago and with less than $1 \%$ of the original forest vegetation remaining (Dafonseca, 1985).

From a carbon cycle perspective, it is of interest that, unlike the temperate and boreal regions, tropical ecosystems have not been "reset" by glaciations (Birks and Birks, 2004), and thus their soils have developed on the same substrate over very long periods (Quesada et al., 2011). As a consequence, for large parts of the Amazon soil plant-available phosphorus pools are low (Quesada et al., 2010), and phosphorus is a limiting element for growth for most forests of the Amazon Basin (Quesada et al., 2012).

Although a large fraction of the Amazon is still covered by intact forest ( $\sim 82 \%$ of the Brazilian legal Amazon by 2010 , e.g. Fearnside, 2005; PRODES, 2010; Regalado, 2010), land use statistics for the Cerrado region within the Brazilian legal Amazon land shows that in 2006 approximately $60 \%$ has been used for pasture and $15 \%$ for cultivation, with the remainder constituting degraded or managed vegetation formation types (Fig. 3; AGROPECUARIA, Brazilian government statistics). The fraction of cultivated land has approximately doubled from 1975 to 2006, and so has its area (Fig. 3). This area change and timing matches approximately the time course and area of deforestation. Taking the area of Brazilian Cerrado (both within and outside the legal Amazon), this originally covered ca. $2 \times 10^{12} \mathrm{~km}^{2}$, but had decreased to ca. $43 \%$ of its original area by 2004 and will be entirely converted to agricultural use by around the year 2030 if annual conversion rates stay at their current level of 0.2 to $0.3 \times 10^{12} \mathrm{~km}^{2} \mathrm{a}^{-1}$ (Machado et al., 2004).

The forests of the Amazon Basin have also been reduced in size at a fast pace, $\sim 0.46 \% \mathrm{a}^{-1}$ since the early 1970 s (e.g. 

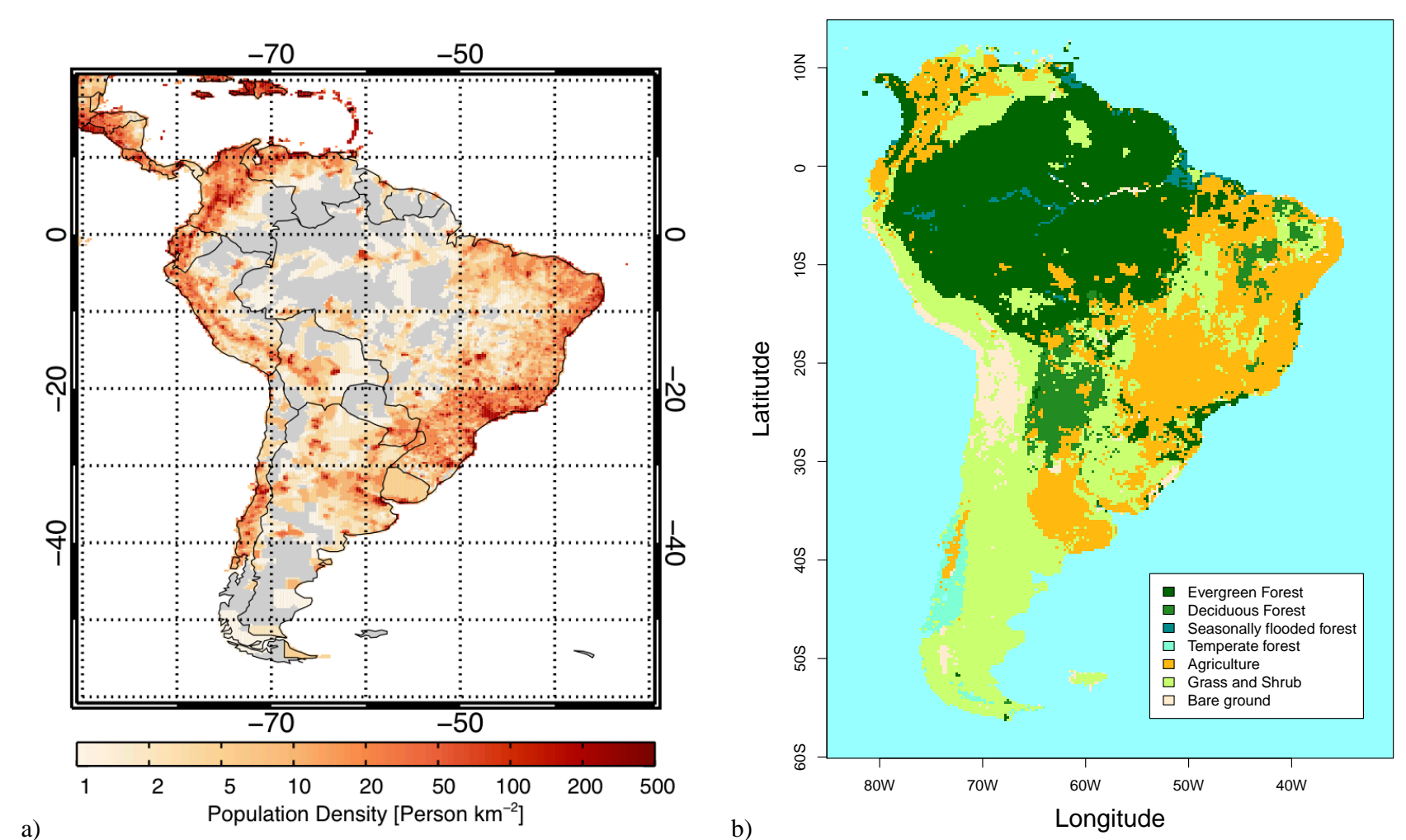

Fig. 1. (a) Population density in South America in the year 2005 (CIESIN, 2005), and (b) land cover map of South America for 1995-2000 derived from remote sensing by Eva et al. (2004).

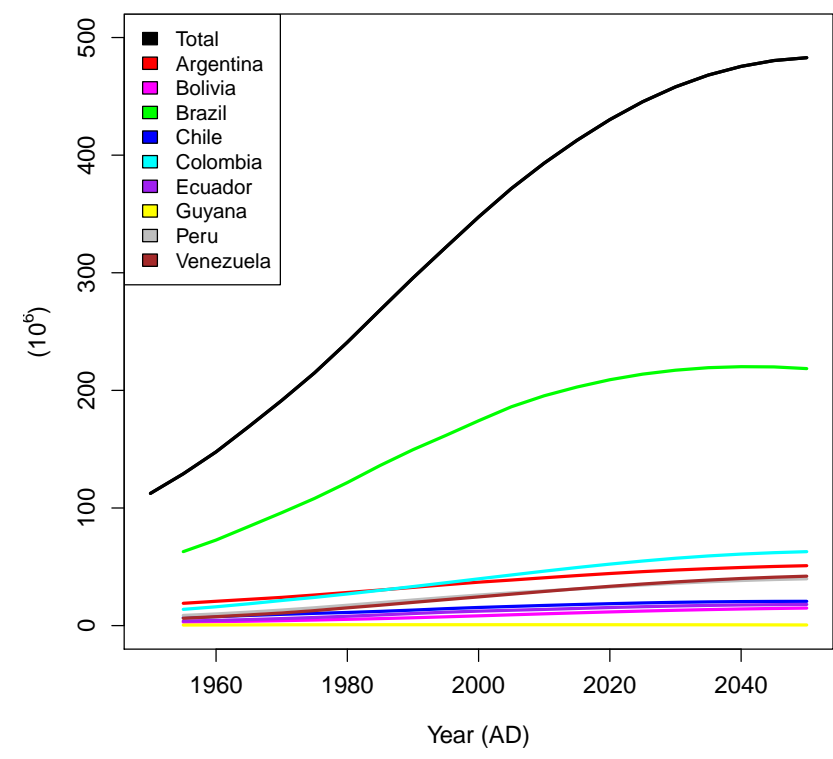

Fig. 2. Observed (until 2007) and predicted population growth for South America by the United Nations (http://esa.un.org/unpd/wpp/ unpp/panel_population.htm).

Fearnside, 2005), with one area of forest transformation currently occurring along the so-called "Arc of Deforestation" along the steadily northwards retreating southern periphery of the Amazon forest region. According to Fearnside (2005), by $200316.2 \%$ of the originally forested portion of Brazil's $\sim 5 \times 10^{6} \mathrm{~km}^{2}$ of legal Amazon region had been deforested. Thus, compared to the Cerrado, a much larger percentage $(83.8 \%)$ of the forest area remains intact. This is in part due to the forest areas being more remote from economic centres, but also the soils of the forest-savanna transition zone are often more fertile than those towards the centre of the Basin (Quesada et al., 2011) and, with rainfall still sufficient, sustain a high level of crop or pasture production. The moister Cerrado regions also have the benefit of an aerial environment less conducive to crop disease pressures (Pivonia et al., 2004), especially in terms of temperature and moisture regimes that are markedly more seasonal than those of the core Amazon forest region. In addition, measures to protect Brazilian Cerrado have been far less reaching than measures to protect Brazilian rainforest (e.g. Fearnside, 2005).

Quantitative data on rates of deforestation for other countries sharing the tropical forests, Peru, Colombia, Bolivia, Guyana, French Guiana, Suriname and Venezuela, are not so readily available. Nevertheless, remote sensing data covering the period from 1984 to 1994 indicate a similar relative deforestation rate for Bolivia as for the Brazilian Amazon (Steininger et al., 2001; $\sim 0.4 \% \mathrm{a}^{-1}$ ). Deforestation rates for Peru have been lower, with rates between $0.1-0.28 \% \mathrm{a}^{-1}$ 


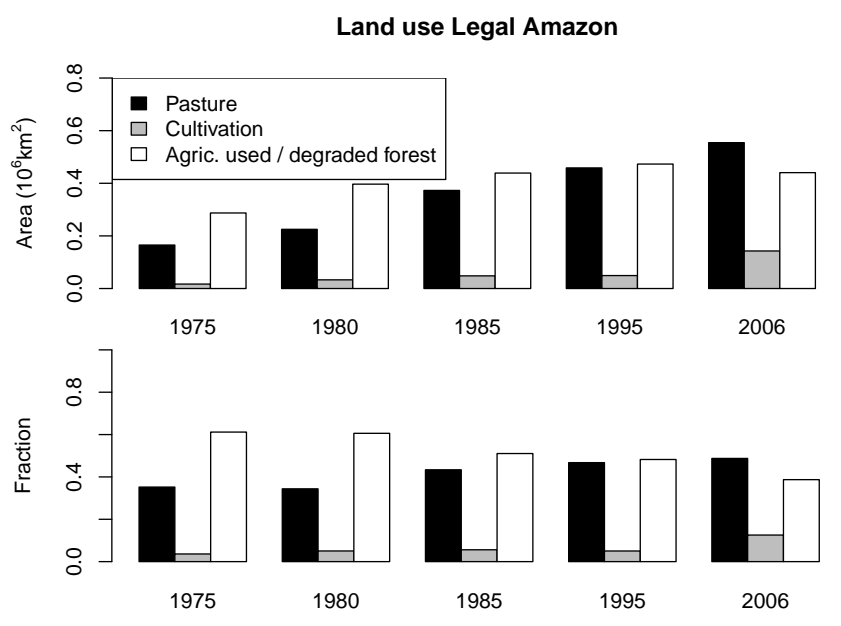

Fig. 3. (a) Agriculturally used land by area in the legal Amazon, and (b) fraction of agriculturally used area by each of the three land use practices (from IBGE, AGROPECUARIA 2006; http://www.ibge. gov.br/home/estatistica/economia/agropecuaria).

(Perz et al., 2005; Oliveira et al., 2007) and with a deforestation rate of $0.1 \% \mathrm{a}^{-1}$ applying to recent years (Oliveira et al., 2007). Although we have not found reliable data on deforestation for all South American countries with tropical forests, a pan tropical study for 1990-1997 based on a combination of $1 \mathrm{~km}^{2}$ and higher resolution remote sensing products (Achard et al., 2002) indicates similarly declining rates of land use change across the entire Basin as is now well documented for Brazil. For both Brazil and Peru, the declining deforestation rates over the last few years (Regalado, 2010; Oliveira et al., 2007) have risen, at least in part, as a result of new government initiatives to try and help protect these forests (see also Nepstad et al., 2006b).

For the more densely populated sub-tropical and temperate zones to the south, land use change has since WWII been at even greater rates than for the tropics, specifically in Paraguay, Argentina and Chile. For these regions, many forest and woodland/scrub areas are now nearly entirely converted to agricultural use (Gasparri et al., 2008; Huang et al., 2009; Echeverria et al., 2006). The arboreal areas of the south have, however, always been of a relatively small magnitude compared to that of tropical South America (Table 4).

\subsection{Climate and climate trends}

Stretching from approximately $10^{\circ} \mathrm{N}$ to $55^{\circ} \mathrm{S}$, South America's weather and climate can be partitioned broadly into three zones characterised by different underlying atmospheric controls. The tropical zone (extending from north of the equator to ca. $22.5^{\circ} \mathrm{S}$ ) has its climate determined mostly by the westerly direction of the atmospheric circulation, the monsoonal circulation during austral summer, and the influence of the Andes on lower tropospheric flow. The subtropical region's climate (ca. $22.5^{\circ}$ to $35^{\circ} \mathrm{S}$ ) is controlled by semi-
Table 3. Population growth and fossil fuel emissions, South America.

\begin{tabular}{lcclc}
\hline $\begin{array}{l}\text { Year } \\
(\mathrm{AD})\end{array}$ & $\begin{array}{c}\text { Population } \\
\left(10^{6}\right)\end{array}$ & $\begin{array}{c}\text { Fossil fuel emissions } \\
\left(\mathrm{Pg} \mathrm{C} \mathrm{yr}^{-1}\right)\end{array}$ & $\begin{array}{l}\text { Year } \\
(\mathrm{AD})\end{array}$ & $\begin{array}{c}\text { Population } \\
\left(10^{6}\right)\end{array}$ \\
\hline \multicolumn{2}{l}{ Censuses } & $\mathrm{a}$ & & \multicolumn{2}{c}{ Projection $^{\mathrm{a}}$} \\
1950 & 112411 & 0.031 & 2015 & 412665 \\
1955 & 129039 & 0.046 & 2020 & 430212 \\
1960 & 147724 & 0.060 & 2025 & 445428 \\
1965 & 169238 & 0.065 & 2030 & 458052 \\
1970 & 191430 & 0.092 & 2035 & 468111 \\
1975 & 214893 & 0.112 & 2040 & 475482 \\
1980 & 240916 & 0.139 & 2045 & 480436 \\
1985 & 268353 & 0.138 & 2050 & 482850 \\
1990 & 295562 & 0.161 & & \\
1995 & 321621 & 0.192 & & \\
2000 & 347407 & 0.222 & & \\
2005 & 371658 & 0.242 & & \\
2010 & 393221 & & &
\end{tabular}

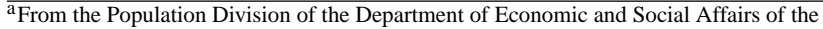
United Nations Secretariat, World Population Prospects: The 2008 Revision, http://esa.un.org/unpd/wpp/unpp/panel_population.htm.

permanent high pressure cells (centred around $30^{\circ} \mathrm{S}$ ), and finally for the mid-latitude southern part, by cyclones and anticyclones associated with the polar front in a generally westerly air flow (e.g. Fonseca de Albuquerque et al., 2009).

Temperature trends over the last few decades estimated, for example, from the CRU climatology (Mitchell and Jones, 2005) reveal a warming trend for the Amazon Basin and Brazil, and constant temperatures or even a slight cooling of the continent to the south of Brazil and in the northwest of the continent (Colombia). Regarding precipitation, sufficiently long records for the purpose of robust trend analysis exist, but unfortunately, with few exceptions, these are only available for outside the Amazon Basin (e.g. Haylock et al., 2006). The pattern revealed by these data is, however, a positive trend in the region from approximately $20^{\circ} \mathrm{S}$ down to Argentina and stretching from the eastern foothills of the Andes to the Atlantic coast. The second pattern is a decreasing trend in a stretch along the Pacific coast and up along the western flank of the Andes (CRU climatology; Mitchell and Jones, 2005; Haylock et al., 2006). The already mentioned increasing precipitation trend from approximately $20^{\circ} \mathrm{S}$ southwards is mirrored by a strongly increasing trend of the La Plata River discharge into the Atlantic at Buenos Aires (e.g. Milly et al., 2005 and references therein). These positive trends are very likely the result of an increasing water vapour outflow from the Amazon Basin towards the south (Rao et al., 1996).

Because from a global carbon cycle perspective the Amazon Basin is by far the most significant South American region, we further describe its climate in slightly greater detail as follows. The Basin's climate is characterised by high annual mean precipitation (between ca. 1.5 and $3.5 \mathrm{~m} \mathrm{a}^{-1}$ ) and relatively constant daily mean temperatures of $24^{\circ}$ to 
Table 4. Estimates of forested area before the onset of intense deforestation in the 20th century.

\begin{tabular}{|c|c|c|c|c|}
\hline Country & $\begin{array}{l}\text { Originally forested } \\
\text { area }\left(10^{6} \mathrm{~km}^{2}\right)\end{array}$ & Year AD & $\begin{array}{l}\text { Region area } \\
\quad\left(10^{6} \mathrm{~km}^{2}\right)\end{array}$ & Source \\
\hline \multicolumn{5}{|c|}{ Amazon and tropical South America } \\
\hline Bolivia & 0.505 & & 0.596 & Killeen et al. (2007b) \\
\hline Colombia (Amazonia and & & & 0.631 & \\
\hline Orinoquia) & & & 0.130 & \\
\hline \multicolumn{5}{|l|}{ Ecuador } \\
\hline Perú & 0.66 & 2005 & 0.647 & Oliveira et al. (2007) \\
\hline Venezuela (Amazonas) & & & 0.178 & \\
\hline Brazil, legal Amazon & 4.0 & 1970 & 5.082 & Fearnside (2005) \\
\hline \multicolumn{5}{|l|}{ Extra-tropical South America } \\
\hline Paraguay, Atlantic forest & 0.624 & 1973 & & Huang et al. (2009) \\
\hline Argentina & 0.265 & 1900 & & Gasparri et al. (2008) \\
\hline $\begin{array}{l}\text { Chile (native forest area, } \\
\text { i.e. not necessarily primary) }\end{array}$ & 0.184 & $1990 \mathrm{~s}$ & & CONAF (1999) \\
\hline
\end{tabular}

$26^{\circ} \mathrm{C}$ (e.g. Nobre et al., 2009; Marengo and Nobre, 2009). The main element of the seasonal variation of the climate is the austral summer monsoon, which occurs during a period from roughly early October to the end of March. The relatively small Northern Hemisphere area has a seasonal cycle out of phase with the rest of the Basin by approximately 6 months. Associated with the (austral) summer monsoon is the rainy season followed by the dry season from approximately April/May onwards. The dry season is not dry in the sense of the Northern Hemisphere mid-to-high latitudes but rather "less wet", typically defined to include months with less than $100 \mathrm{~mm}$ of rainfall.

The main mode of inter-annual variation over recent decades has been associated with the El Niño and La Niña oscillation, collectively referred to as the El Niño-Southern Oscillation (ENSO). El Niño phases are associated with drier conditions in the north of the Basin and vice versa (Costa and Foley, 1999). Not all variation is controlled by ENSO (i.e. Pacific sea surface temperature (SST) variations). For example, cross-equatorial Atlantic sea surface temperature differences influence the ITCZ (Intertropical Convergence Zone) location and thereby precipitation patterns as well (e.g. Yoon and Zeng, 2010). Also, on multi-decadal scales the dominance of Pacific and Atlantic influence vary (e.g. Yoon and Zeng, 2010; Espinoza et al., 2011).

Historically, Amazonian droughts have occurred fairly regularly, with a particularly intense episode in 1926 (Williams et al., 2005). Other unusually dry periods in the 20th century, mostly associated with El Niño, occurred in 1935-1936, 1966-1967, 1979-1980, 1983 and 1992 (Marengo and Nobre, 2009). In more recent years, there have been strong droughts in parts of the Amazon in 1997/98, 2005 and 2010, with the latter two apparently related to Atlantic SST anomalies (Yoon and Zeng, 2010).
Similar to global land temperature trends, the Amazon region has warmed by approximately $0.5-0.6^{\circ} \mathrm{C}$ over the last few decades (1960 to 2000, e.g. Victoria et al., 1998; Malhi and Wright, 2004). Published analyses of precipitation trends by various authors differ in the periods chosen, and climatologies or station data used (Espinoza et al., 2009). This is partially due to the sparsity of precipitation records in the Amazon already noted. Nevertheless, river discharge data should also provide a good diagnostic of hydrological cycle changes with the rate of discharge to the ocean providing a measure of the Basin-wide precipitation in excess of plant requirements, and the following patterns emerge when analysing trends in Amazon river discharge at Obidos (Callède et al., 2004; Fig. 4), located approximately $800 \mathrm{~km}$ inland from the estuary of the Amazon River. At this point the River drains a basin of $\sim 4.7 \times 10^{6} \mathrm{~km}^{2}$, or roughly $77 \%$ of the Amazon Basin proper. Although such data suffer from a shortcoming that the measured discharge is "blind" to whether water falling as precipitation has been recirculated via transpiration or not, as is shown in Fig. 4, the last $\sim 100 \mathrm{yr}$ exhibit a substantial increasing trend (approximately $20 \%$ change from 1900 to 2010), arguing for a similar trend in annual mean net precipitation. A second noteworthy feature which can be inferred from Fig. 4 is that wet seasons have become more pronounced and inter-annual variation has increased over the last decades.

\subsection{Potential vegetation responses and feedbacks with climate}

One widely cited hypothesis states that the anticipated increase in frequency and intensity of anomalously dry periods in a warming climate may lead to a large reduction in forest vegetation and replacement by savanna, grasslands or even desert by 2100 (White et al., 1999; Cox et al., 2000; 


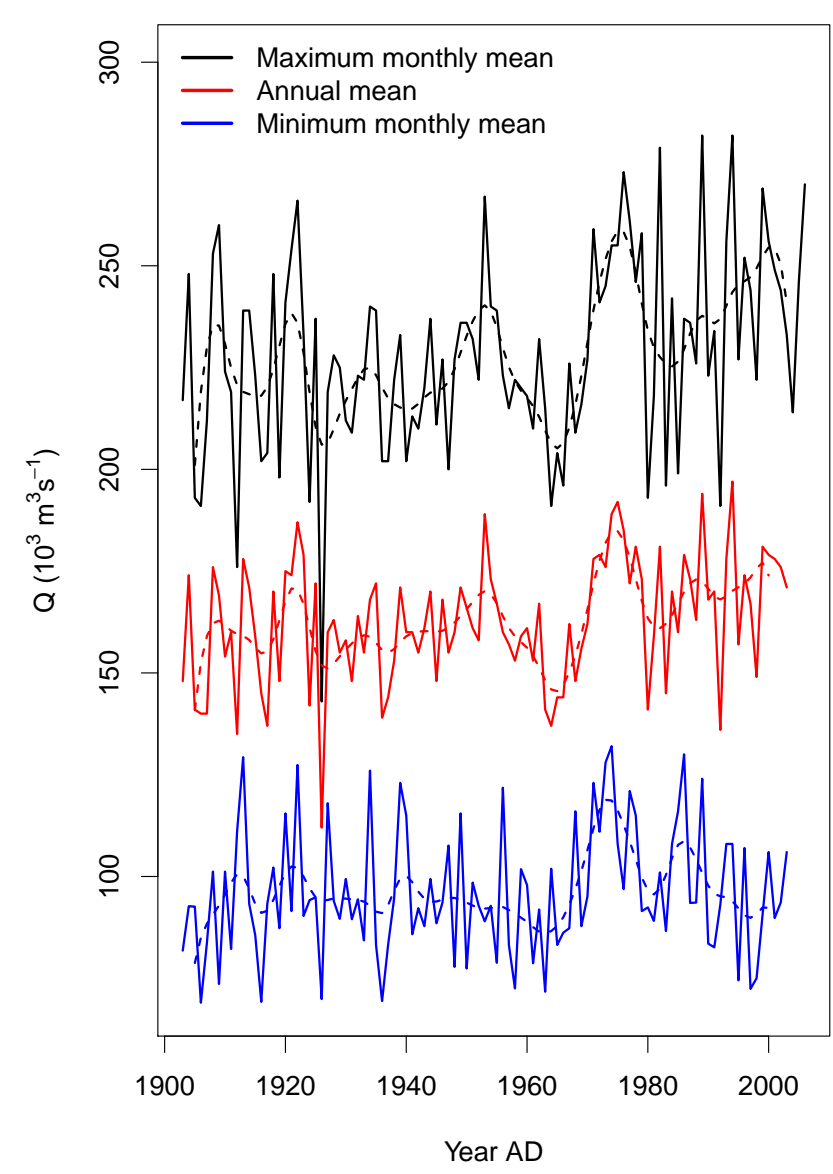

Fig. 4. Maximum monthly (black), minimum monthly (blue), and annual mean (red) river discharge at Obidos measured by Hydrological Service ANA, Brazil, http://www2.ana.gov.br/, and, where measurements are missing, estimated from upstream river gauge stations by Callède et al. (2004), based on data from the same datasource.

Oyama and Nobre, 2003). This hypothesis has, amongst others, been suggested by the first fully coupled climate-carbon cycle modelling results (Cox et al., 2000). However, more recent versions with a further evolved coupled climate-carbon cycle model from the same institution (Hadley Centre UK) do not show such a biome switch for the Amazon region (C. Jones, personal communication). Indeed, a data-oriented analysis by Malhi et al. (2009) which corrects for the fact that climate models are predicting a too dry contemporary climate finds a much lesser effect of a changing climate on tropical forest vegetation, and a climate ensembles approach shows the likelihood of forest "dieback" to be low (Poulter et al., 2010). Thus, although the possible risk of large-scale climate change induced forest "die-back" remains a concern and requires ongoing analysis and research, when correctly calibrated only a minority of climate models predict this possibility at the current time.
Inventory data is especially of use for analysis of year-onyear features, and in some instances can give indications of what the Amazon forest response might be in a future climate state (for instance, warm years might show features that become prominent in a continually warmer greenhouse gas-enriched world). The effect of atypical dry conditions on forest function have been examined by Phillips et al. (2009) based on tree growth and mortality data of a pan-tropical forest census network. Looking at forest dynamics following the "2005 drought" they found a small but significant increase in mortality compared to the long-term pre-2005 mean rate, suggesting a potential sensitivity of forest dynamics to more frequent or intense dry periods.

Besides climate alone, the $40 \%$ increase in atmospheric $\mathrm{CO}_{2}$ today over its pre-industrial concentration could in principle affect functioning of vegetation, specifically increasing photosynthetic rates, decreasing stomatal density and conductance, and thus leading to higher water use efficiency (e.g. Woodward, 1987; Lloyd and Farquhar, 1996, 2008). There are indications based on trends in the ${ }^{13} \mathrm{C}:{ }^{12} \mathrm{C}$ ratio of wood and leaf cellulose (the carbon isotopic ratio of wood is a strong function of stomatal conductance (e.g. O'Leary, 1988)) that there has indeed been down-regulation of stomatal conductance in parts of the Amazon forests (Hietz et al., 2005), although unambiguous attribution to mechanisms remains difficult (Seibt et al., 2008). Amazon River discharge and Basin-wide precipitation seem indeed, not having increased at the same rate, consistent with a trend in down-regulation of stomatal conductance (i.e. reduced evapotranspiration; Gedney et al., 2006). Higher atmospheric $\left[\mathrm{CO}_{2}\right]$ may also favour the $\mathrm{C}_{3}$ photosynthetic pathway (mainly trees) over the $\mathrm{C}_{4}$ pathway (grasses, e.g. Ehleringer and Cerling, 2002). Several studies document forest moving into savanna at the southern border of the Amazon forest-to-savanna transition zone with a speed on the order of $50 \mathrm{~m} \mathrm{a}^{-1}$ over the last $3000 \mathrm{yr}$, this being attributed to a shift in the ITCZ (Mayle et al., 2000). Significantly higher rates of "desavannisation" over the last decades are consistent with a $\left[\mathrm{CO}_{2}\right]$ induced shift from $\mathrm{C}_{4}$ towards $\mathrm{C}_{3}$ plants (e.g. Pessenda et al., 1998; Marimon et al., 2006).

\section{Flux estimates}

\subsection{Fossil fuel and ethanol production and use}

Currently, total fossil fuel emissions from South America are estimated to be $0.26 \mathrm{PgCa}^{-1}$, or approximately $3 \%$ of the global total fossil fuel emissions (Boden et al., 2011; data available up to 2007). The increase since the 1950s has been approximately exponential, with an annual increase rate of about $\sim 8 \% \mathrm{a}^{-1}$ from $1950-1980$ but falling back to $3 \% \mathrm{a}^{-1}$ during the period from 1980-2008. (Figs. 6 and S1). Use of fossil fuels on a per person (pp) basis in 2005 was $0.65 \mathrm{MgC} \mathrm{pp}^{-1} \mathrm{a}^{-1}$. This compared to a global 

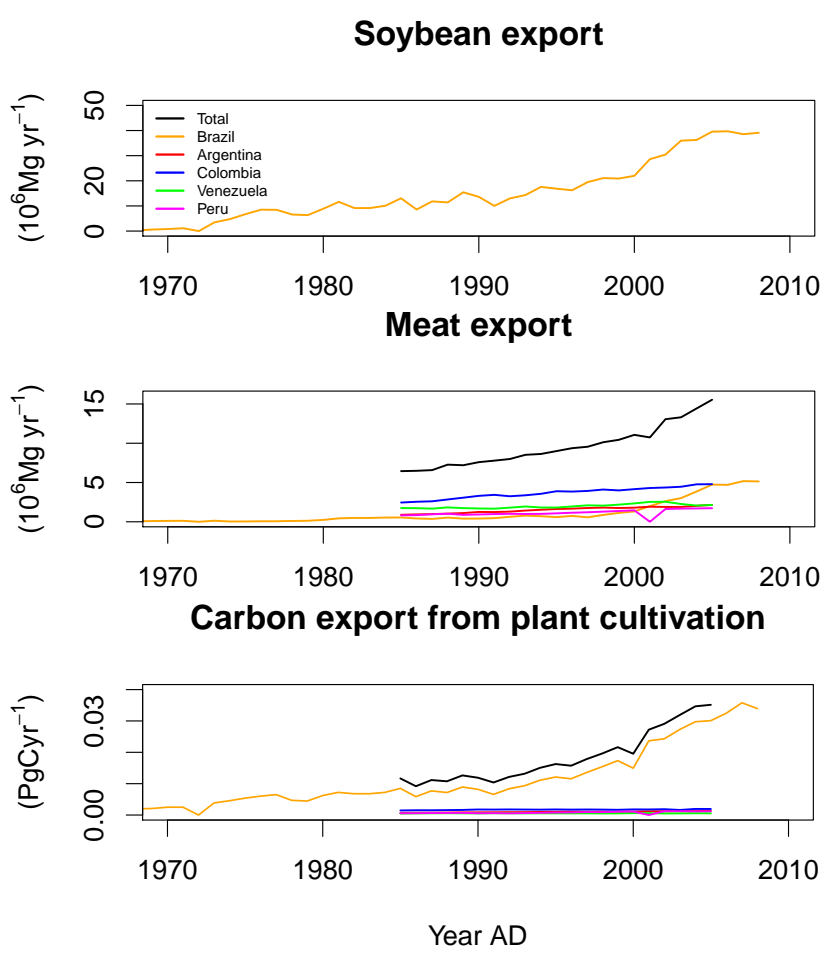

Fig. 5. Exports of agricultural products from five main South American agricultural exporters according to FAO statistics (http: //faostat.fao.org).

average of $1.22 \mathrm{MgCpp}^{-1} \mathrm{a}^{-1}$ and is less than $15 \%$ of more highly industrialised countries such as the USA (ca. 4.9 $\mathrm{Mg} \mathrm{C} \mathrm{pp}^{-1} \mathrm{a}^{-1}$ ).

One interesting aspect of fuel use in Brazil is that around $40 \%$ of the total fuel used for motor vehicles and other combustion engines is ethanol $\left(\mathrm{C}_{2} \mathrm{H}_{6} \mathrm{O}\right)$ produced through the distillation of fermenting sugar cane (Macedo et al., 2008). Nevertheless, we do also note that biofuel usage is not included in the fossil fuel totals above. Compared to other crops, the ratio of renewable energy of ethanol/fossil fuel energy used to produce ethanol is high (8.3; Macedo et al., 2008). Ethanol utilization in Brazil in 2006 was $14.1 \times 10^{6} \mathrm{~m}^{3}$. To put this into perspective, the $\mathrm{C}$ flux to the atmosphere from burning ethanol in 2006 amounts to $\sim 5.8 \mathrm{Tg} \mathrm{Ca}^{-1}$ (the density of ethanol which has a carbon content of $52 \%$ is $0.789 \mathrm{Mg} \mathrm{m}^{-3}$ ), which is $\sim 5 \%$ of the total fossil fuel emissions from Brazil. However, because the carbon biomass used in ethanol production must have originated from atmospheric $\mathrm{CO}_{2}$ as recently assimilated by local sugar cane crops, these emissions do not contribute to the net carbon balance.

Ethanol production from sugar cane in Brazil goes back to the 1920s, originally developed as a means to utilize sugar cane overproduction. Currently, the main region where sugar cane is planted is in the southeast of Brazil (Sao Paulo State $\sim 66 \%$, Parana State $\sim 9 \%$, Minas Gerais State

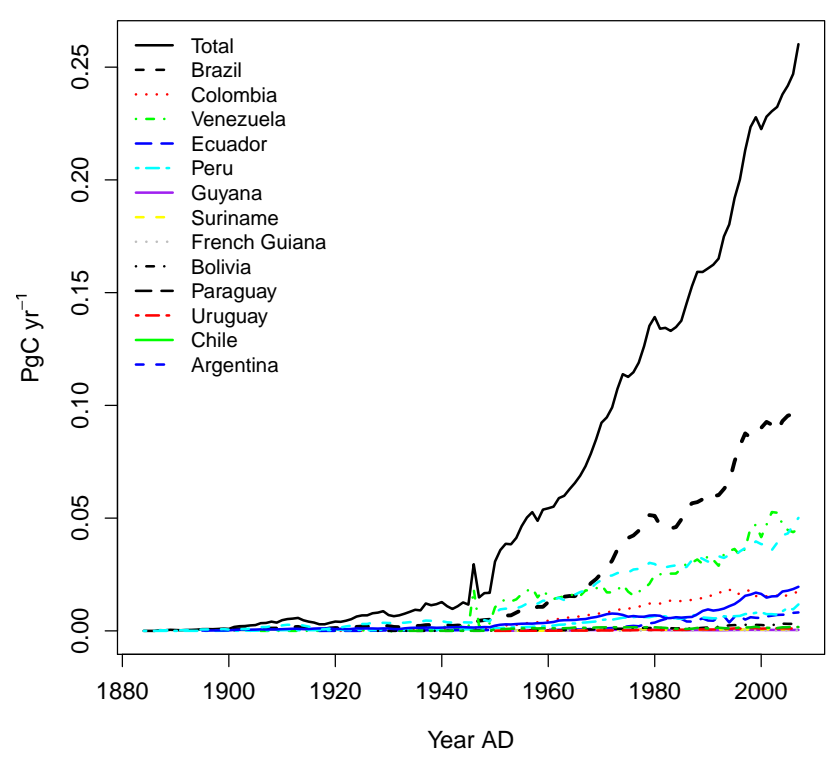

Fig. 6. Fossil fuel emissions estimated based on national energy statistics (Marland et al., 2008).

$\sim 9 \%$; UNICA, 2011). Both the production and export of ethanol have risen strongly over the last decade (production from 11.5 to $27.5 \times 10^{6} \mathrm{~m}^{-3}$ and export from $0.2 \times 10^{6}$ to $5.1 \times 10^{6} \mathrm{~m}^{3}$ in the years 2000 and 2009 , respectively; UNICA Brazil, 2011). Although the area of ca. $7 \times 10^{6} \mathrm{ha}^{-1}$ currently under sugarcane is not large compared to the ca. $200 \times 10^{6} \mathrm{ha}^{-1}$ pasture (UNICA, 2011), there is strong concern and evidence that if expanding export markets are permitted to drive expansion of sugar cane plantation areas, then the deforestation frontier will move further north (e.g. DeFries et al., 2010; Figs. 3 and 5).

\subsection{Deforestation}

Historically, global deforestation carbon emissions have been based on a book-keeping approach as detailed by the pioneering study of Houghton et al. (1983). The area change data associated with land-use-change-related carbon fluxes used in these studies have traditionally been from the Food and Agriculture Organization of the United Nations (FAO), with the data provided to FAO by countries' governments (see, e.g. Houghton, 2003). More recently, independent land use change area estimates - particularly those caused by deforestation - based on remote sensing data and various statistical scaling approaches have become available (PRODES, Brazilian government; see Morton et al., 2005; Hansen et al., 2008; Achard et al., 2002, 2004). One advantage of these latter estimates is that they are more easily verifiable than the FAO data. Based on rates of change, it is then possible to estimate land-use-change-related fluxes based on spatially explicit forest biomass estimates, e.g. from the RAINFOR forest census network (e.g. Malhi et al., 2002; Phillips 
et al., 2009), fraction of biomass combusted, and estimates of lagged carbon release and uptake due to decomposition of dead organic carbon and recovery after deforestation, respectively (Houghton et al., 1983).

To progress along similar lines, in this study, we first compare the time course of forest area change (Fig. 7) based on FAO data (see e.g. Houghton, 2003), provided for this study by R. A. Houghton, with those coming from independent remote sensing-based estimates using sensors of various spatial resolutions. In some cases the remote sensing estimates are based on a hierarchical approach using increasingly spatially resolving sensors to first identify "deforestation hotspots" and then zoom in to hotspot areas using higher accuracy (Achard et al., 2002; Hansen et al., 2008). Figure 7 also includes estimates of changes in agricultural land use provided by the Brazilian government (Instituto Brasileiras de Geografia e Estatistica, Agropecuaria, 2006), which permits some test of consistency of the deforestation numbers. Although by no means a new insight, it is, however, clear that compared to the various independent remote sensing-based estimates (the numerical data are given in Table 5), the FAO area deforested numbers are substantially larger, even when considering that the different estimates are not for exactly the same regions. The independent remote sensing-based estimates are quite consistent amongst each other and also consistent with the estimates of changes in agricultural land use in Brazil provided by the Brazilian government mentioned earlier on. We therefore base our further attempt to estimate carbon fluxes associated with forest clearing on the published remote sensing estimates of forest area change rates (i.e. independently from the deforestation numbers of FAO).

The deforested area provides an upper bound on carbon release to the atmosphere if it is assumed that all forest carbon (including roots and necromass) and soil carbon fraction is lost after deforestation. Then the total carbon to be lost, $F_{\text {ld } \rightarrow \text { at }}$, is the product of the mean tree and soil organic matter carbon per area multiplied by the deforested area, $\Delta A$, i.e.

$F_{\text {ld } \rightarrow \text { at }}=r_{\mathrm{C}: \text { biom }}\left(B_{\text {trees }}+r_{\text {soil release }} \mathrm{C}_{\text {soil }}\right) \Delta A$.

Here, $r_{\mathrm{C}: \text { biom }}$ is the carbon to biomass weight ratio, $B_{\text {trees }}$ is tree biomass per area, $r_{\text {soil release }}$ is the fraction of soil organic carbon released to the atmosphere, and $\mathrm{C}_{\text {soil }}$ is soil organic carbon content per area. By taking into account the time lags between the decomposition of dead organic material after deforestation and similarly gradual replacement of the deforested area by a new (or potentially similar) vegetation type (Houghton et al., 1983), one can then estimate fluxes from differences in stocks. This provides a simple alternative to the accounting of individual fluxes within the continent which would involve, for example, a separation of deforestationrelated emissions caused by fire from those which form part of a natural cycle (see Sect. 1). Below, we implement a simplified version of this so-called "book-keeping" procedure with simple conceptualisation of the time lags in decomposition and time-course of establishment of a new vegetation cover. Our purpose is, in this relatively simple way, to bracket likely values of deforestation fluxes; our estimates reflecting the uncertainties of lags in carbon release and recovery whilst also taking full advantage of published deforested area estimates based on remote sensing. Specifically, we assume exponential decay of dead organic material left over from a deforestation event, i.e.

$\Delta \mathrm{C}=-\lambda_{\text {resp }} \mathrm{C} \Delta t$,

where $\mathrm{C}$ is the carbon stock, $\Delta \mathrm{C}$ the annual release of carbon to the atmosphere due to decomposing leftover debris, $\Delta t$ a discrete time interval (one year), and $\lambda_{\text {resp }}$ a decay constant. Establishment of new vegetation is assumed to approach steady-state carbon content following

$\mathrm{C}(t)=\mathrm{C}_{\text {steady }}\left(1-e^{-\lambda_{\text {rgrwth }} t}\right)$,

where $\lambda_{\text {rgrwth }}$ is the inverse of the time scale to reach a new steady state. The total flux to the atmosphere in year $t$ caused by deforestation during year $t$ and decomposition of dead organic material remaining from deforestation events in previous years is

$F_{\mathrm{ld} \rightarrow \mathrm{at}}^{\mathrm{tot}}(t)=\sum_{t_{\mathrm{def}}=-\infty}^{t} F_{\mathrm{ld} \rightarrow \mathrm{at}}\left(t, t_{\mathrm{def}}\right)$,

where $F_{\mathrm{ld} \rightarrow \mathrm{at}}\left(t, t_{\mathrm{def}}\right)$ is the flux from land ("ld") to the atmosphere ("at") in year $t$ due to deforestation in year $t_{\text {def }}$ in the past. Similarly, the total flux from the atmosphere to land due to re-establishment of either forest or another vegetation type (we distinguish cultivation, secondary forest and pasture) is given by

$F_{\mathrm{ld} \rightarrow \mathrm{at}}^{\mathrm{tot}}(t)=\sum_{t_{\mathrm{def}}=-\infty}^{t} \sum_{\mathrm{lu}} \alpha_{\mathrm{lu}} F_{\mathrm{at} \rightarrow \mathrm{ld}}\left(t, t_{\mathrm{def}}\right)$,

where $F_{\mathrm{at} \rightarrow \mathrm{ld}}\left(t, t_{\mathrm{def}}\right)$ is carbon uptake in the wake of deforestation in year $t_{\mathrm{def}}$, and $\alpha_{\mathrm{lu}}$ is the fraction of originally deforested land being replaced by land use type "lu" each year (for details see Appendix). For $\alpha_{\mathrm{lu}}$ we use the values from Brazilian government statistics (AGROPECUARIA; Fig. 3), which due to lack of the same statistics for other countries we assume to be similar. The model parameters are defined and values given in Table 6. Explicit expressions for $F_{\mathrm{at} \rightarrow \mathrm{ld}}\left(t, t_{\mathrm{def}}\right)$ and $F_{\mathrm{at} \rightarrow \mathrm{ld}}\left(t, t_{\mathrm{def}}\right)$ can be derived and are given in the Appendix. Following our goal to use deforestation area estimates based on published, reproducible studies as much as possible, we have attempted an exhaustive search of the literature (Tables 5 and 7). Unfortunately, there are countries for which we did not succeed with our search. For three countries, Brazil, Argentina and Paraguay, we may reconstruct reasonably well the land use change history from 1970 onwards. To proceed, we conceptually separate tropical from extratropical forest regions. To estimate tropical area 
Table 5a. Deforestation.

\begin{tabular}{|c|c|c|c|c|c|}
\hline $\begin{array}{l}\text { Year } \\
(\mathrm{AD})\end{array}$ & $\begin{array}{l}\text { Area deforested } \\
\left(10^{3} \mathrm{~km}^{2}\right)\end{array}$ & $\begin{array}{l}\text { Forest area } \\
\left(10^{6} \mathrm{~km}^{2}\right)\end{array}$ & $\begin{array}{l}\text { Year } \\
(\mathrm{AD})\end{array}$ & $\begin{array}{l}\text { Area deforested } \\
\quad\left(10^{3} \mathrm{~km}^{2}\right)\end{array}$ & $\begin{array}{l}\text { Forest area } \\
\left(10^{6} \mathrm{~km}^{2}\right)\end{array}$ \\
\hline \multicolumn{6}{|c|}{ Brazilian legal Amazon } \\
\hline Pre-1970 & & $4.000^{\mathrm{a}}$ & 1993 & 14.9 & 3.614 \\
\hline Pre-1978 & & 3.931 & 1994 & 14.9 & 3.599 \\
\hline 1978 & 20.4 & 3.890 & 1995 & 29.1 & 3.570 \\
\hline 1979 & 20.4 & 3.869 & 1996 & 18.2 & 3.552 \\
\hline 1980 & 20.4 & 3.849 & 1997 & 13.2 & 3.538 \\
\hline 1981 & 20.4 & 3.829 & 1998 & 17.3 & 3.521 \\
\hline 1982 & 20.4 & 3.809 & 1999 & 17.3 & 3.504 \\
\hline 1983 & 20.4 & 3.788 & 2000 & 18.2 & 3.486 \\
\hline 1984 & 20.4 & 3.767 & 2001 & 18.2 & 3.467 \\
\hline 1985 & 20.4 & 3.747 & 2002 & 21.7 & 3.446 \\
\hline 1986 & 20.4 & 3.727 & 2003 & 25.4 & 3.418 \\
\hline \multirow[t]{2}{*}{1987} & 20.4 & $3.706^{\mathrm{a}}$ & 2004 & 27.8 & 3.399 \\
\hline & & & 2005 & 19.0 & 3.385 \\
\hline 1988 & 21.1 & $3.684^{b}$ & 2006 & 14.3 & 3.373 \\
\hline 1989 & 17.8 & 3.667 & 2007 & 11.7 & 3.360 \\
\hline 1990 & 13.7 & 3.653 & 2008 & 12.9 & 3.352 \\
\hline 1991 & 11.0 & 3.642 & 2009 & 7.5 & 3.346 \\
\hline 1992 & 13.8 & 3.629 & 2010 & 6.5 & $3.340^{\mathrm{b}}$ \\
\hline \multicolumn{6}{|c|}{ Latin America humid tropical forest ${ }^{\mathrm{c}}$} \\
\hline 1990 & & $6.69 \pm 0.57$ & & & \\
\hline 1991 & $25.0 \pm 1.4$ & & & & \\
\hline 1992 & $25.0 \pm 1.4$ & & & & \\
\hline 1993 & $25.0 \pm 1.4$ & & & & \\
\hline 1994 & $25.0 \pm 1.4$ & & & & \\
\hline 1995 & $25.0 \pm 1.4$ & & & & \\
\hline 1996 & $25.0 \pm 1.4$ & & & & \\
\hline 1997 & & $6.53 \pm 0.56$ & & & \\
\hline
\end{tabular}

\begin{tabular}{llll}
\hline & \multicolumn{3}{c}{ Latin America humid tropical forest } \\
\hline Brazil & & \multicolumn{2}{c}{ Americas sans Brazil } \\
2000 & $0.72 \% \mathrm{yr}^{-1}$ & 2000 & $0.25 \% \mathrm{yr}^{-1}$ \\
2001 & $0.72 \% \mathrm{yr}^{-1}$ & 2001 & $0.25 \% \mathrm{yr}^{-1}$ \\
2002 & $0.72 \% \mathrm{yr}^{-1}$ & 2002 & $0.25 \% \mathrm{yr}^{-1}$ \\
2003 & $0.72 \% \mathrm{yr}^{-1}$ & 2003 & $0.25 \% \mathrm{yr}^{-1}$ \\
2004 & $0.72 \% \mathrm{yr}^{-1}$ & 2004 & $0.25 \% \mathrm{yr}^{-1}$ \\
\hline
\end{tabular}

${ }^{a}$ Fearnside (2005)

${ }^{\mathrm{b}}$ PRODES, INPE, and Brazil, based on remote sensing.

${ }^{c}$ Achard et al. (2002), based on remote sensing.

${ }^{\mathrm{d}}$ Hansen et al. (2008), based on remote sensing.

deforestation over time, we scale the Brazilian tropical deforestation numbers with a factor (100/79) as estimated by Hansen et al. (2008) for the 1990s (i.e. 1990-1999). For extratropical South America we use the sum of the Argentina and Paraguay numbers. This will lead to a small underestimate because we neglect Chilean and Uruguayan deforestation. For all of South America, $\alpha_{\mathrm{lu}}$ is derived from Brazilian government statistics (AGROPECUARIA; Fig. 3), thus assuming the same land use time history after deforestation for all of South America.
Simplifications and sources of uncertainty include the limitations due to the simple model formulation itself, the use of a spatial average wood density (supported by an analysis of RAINFOR data), scaling of deforestation area estimates, assumption of similar land use transition time patterns in South America as in the legal Amazon region, and uncertainty in the time scales for the decay of forest debris after deforestation and for the re-establishment of a new vegetation type after deforestation. Error propagation yields a total uncertainty 
Table 5b. Deforestation.

\begin{tabular}{lcr}
\hline $\begin{array}{l}\text { Year } \\
\text { (AD) }\end{array}$ & $\begin{array}{r}\text { Area deforested } \\
\left(10^{3} \mathrm{~km}^{2}\right)\end{array}$ & $\begin{array}{r}\text { Forest area } \\
\left(10^{6} \mathrm{~km}^{2}\right)\end{array}$ \\
\hline $\begin{array}{l}\text { Andean Amazon } \\
\text { Bolivian Amazon }\end{array}$ & \\
\hline $1984-1987$ & $15.5^{\mathrm{e}}$ & $0.447^{\mathrm{e}}$ \\
1989-1994 & $24.7^{\mathrm{e}}$ & $0.437^{\mathrm{e}}$ \\
$1990-2000$ & $15.06^{\mathrm{f}}$ & \\
$2000-2005$ & $22.47^{\mathrm{f}}$ & $0.409^{\mathrm{f}}$ \\
$2005 / 06$ & & $0.66^{\mathrm{g}}$ \\
\hline Peruvian Amazon & & \\
\hline $1985-1990$ & $9.38^{\mathrm{h}}$ & \\
$1999-2005$ & $3.88^{\mathrm{g}}$ & \\
\hline Colombia no reliable data found (although see Sierra, 2000) \\
Venezuela no reliable data found \\
Ecuador no reliable data found \\
\hline Extratropical South America \\
Paraguay
\end{tabular}

${ }^{\mathrm{e}}$ Steininger et al. (2001), based on remote sensing (Landsat images, wall-to-wall).

${ }^{\mathrm{f}}$ Killeen et al. (2007b), based on remote sensing (Landsat images, wall-to-wall).

gOliveira et al. (2005), based on remote sensing (Landsat images, wall-to-wall).

${ }^{\mathrm{h}}$ Perz et al. (2005)

${ }^{\mathrm{i}}$ Huang et al. (2007), based on remote sensing.

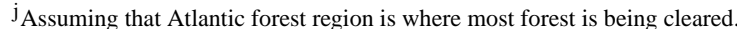

${ }^{\mathrm{k}}$ Atlantic forest only.

${ }^{1}$ Gasparri et al. (2008), based on remote sensing (Landsat images, wall-to-wall).

of the annual flux to the atmosphere due to deforestation of approximately $\pm 25 \%$ (see Appendix).

Our estimates indicate a net flux to the atmosphere of around $0.5 \mathrm{Pg} \mathrm{Ca}^{-1}$ due to deforestation and land use change in South America over the last two decades or so (Figs. 7 and 8). This has persisted over the last few years, despite the remarkable decrease in deforestation in the Brazilian Amazon, because of lagged fluxes caused by earlier deforestation. Our estimate is smaller than the FAO estimate used in the recent study of Pan et al. (2011) for South America. The difference is smaller than expected based on the estimates of deforested areas alone, which by themselves differ strongly (Fig. 7). This is because the net flux to the atmosphere is the difference of release and regrowth and the regrowth estimate of Pan et al. (2011) is also much larger than ours. Thus, the differences tend to compensate each other, and thus the global budget is not changed much.

\subsection{Amazon forest censuses}

Forest carbon storage and its trends have been monitored over the last few decades by keeping track of the diameter of all living trees within a permanent plot network. Two measurement strategies have been followed. One strategy (the CTFS (Center for Tropical Forest Science - Smithsonian Institution) approach) samples a few plots of a relatively large size, $16-50 \mathrm{ha}$, of which there are currently three in tropical America (Chave et al., 2008). The other (the RAINFOR network; Phillips et al., 2009) currently samples 136 plots, mostly of 1 ha, covering the main axes of forest growth variation (El Niño, soil fertility, dry season length; O. Phillips, personal communication). The censuses from the RAINFOR network have revealed a positive trend in aboveground biomass growth in the Amazon (dry matter, in units $\mathrm{ha}^{-1} \mathrm{a}^{-1}$ ) reported first by Phillips et al. (1998) and recently summarised in Phillips et al. (2009). These measurements do not include soil carbon trends, but this time series of inventory data is a significant step forward in understanding recent trajectories in the amount of carbon stored by Amazon forests. Given the labour and logistically-intensive requirements associated with working in remote locations, then inevitably the number of plots remains relatively few compared to what might be considered ideal, and, of course, that data is only available for the last few decades. Thus, there has been some concern expressed that the biomass accumulation (NEP) estimates are biased toward high estimates because rare large-scale disturbance events involving large biomass losses have not been captured (Fisher et al., 2008). Nevertheless, an examination of this concern (Gloor et al., 2009) has concluded that, using a realistic (observed) disturbance severity and return time distribution, the results of a positive forest biomass gain trend based on the existing census network remain statistically significant and are unlikely to be an artefact. Other criticisms such as the uncertainty induced by using allometric equations for biomass estimation have been assessed and have also been demonstrated to have only minor impact on the regional sink estimates (Lewis et al., 2009). Results from a similar analysis based on the CTFS forest plots has confirmed a pan-tropical biomass increase trend, although of lesser magnitude (Chave et al., 2008). Here we do not use the results from this latter study, especially as only one plot is located in tropical South America.

We extrapolate the biomass changes reported by Phillips et al. (2009) to the tropical forests of all tropical South America by first assuming a carbon content of wood of $50 \%$ by dry-mass. Furthermore, following the compilation of Lewis et al. (2009; Supplement, p. 30) for estimating intact forest area in the year 2000, we obtain a value of $703.3 \pm$ $142 \times 10^{6}$ ha (the value used is the mean of $630.5 \times 10^{6}$ ha from GLC 2000 (Global Land Cover Mapping for the Year 
Table 6. Parameters of book-keeping model to estimate deforestation carbon fluxes.

\begin{tabular}{|c|c|}
\hline$\alpha=0.28$ & $\begin{array}{l}\text { Fraction of dead biomass immediately released to } \\
\text { the atmosphere after a deforestation event } \\
\text { (Houghton et al., 1983). }\end{array}$ \\
\hline$\alpha_{1 \mathrm{u}}$ & $\begin{array}{l}\text { Fraction of originally deforested land being replaced } \\
\text { by land use type lu where lu can either be } \\
\text { cultivation, secondary forest, or pasture. We estimate } \\
\text { these fractions from agricultural statistics for the legal } \\
\text { Amazon (AGROPECUARIA, Brazil) and assume the } \\
\text { same ratios throughout South America. }\end{array}$ \\
\hline $\begin{aligned} \mathrm{C}_{\text {oldgrowth forest }}= & r_{\mathrm{C}: \mathrm{Bio}}\left(1+r_{\text {blwgrd:abvgrd }}\right) \\
& \cdot 220\left(\mathrm{MgC} \mathrm{ha}^{-1}\right)\end{aligned}$ & $\begin{array}{l}\text { Mean alive forest tree carbon content per area based } \\
\text { on RAINFOR forest censuses. }\end{array}$ \\
\hline $\mathrm{C}_{\text {forest }}$ soil $=291\left(\mathrm{MgC} \mathrm{ha}^{-1}\right)$ & $\begin{array}{l}\text { Oldgrowth forest soil carbon content } \\
\text { per area (Jobaggy and Jackson, 2000). }\end{array}$ \\
\hline $\mathrm{C}_{\text {pasture }}=8\left(\mathrm{MgCha}^{-1}\right)$ & $\begin{array}{l}\text { Carbon per area in vegetation of } \\
\text { pasture (Barbosa and Fearnside, 1996). }\end{array}$ \\
\hline $\mathrm{C}_{\text {cultivation }}=50\left(\mathrm{MgCha}^{-1}\right)$ & $\begin{array}{l}\text { Carbon per area in cultivation vegetation } \\
\text { (Barbosa and Fearnside, 1996). }\end{array}$ \\
\hline $\mathrm{C}_{\text {secdry forest }}=0.8^{*} \mathrm{C}_{\text {oldgrowth forest }}$ & $\begin{array}{l}\text { Carbon per area in secondary forest vegetation } \\
\text { (based on RAINFOR data). }\end{array}$ \\
\hline$r_{\text {blwgrd:abgrd }}=0.2$ & $\begin{array}{l}\text { Ratio of below- to aboveground tree biomass } \\
\text { (Malhi et al., 2010). }\end{array}$ \\
\hline$r_{\text {soil }}$ release $=0.22$ & $\begin{array}{l}\text { Fraction of soil C released to the atmosphere } \\
\text { when forest is converted to agriculture (Murty et al., } \\
\text { 2002) (while according to Murty et al., } 2002 \text { the } \\
\text { transition of forest to pasture does not lead to } \\
\text { significant soil carbon loss). }\end{array}$ \\
\hline$r_{\mathrm{C}: \mathrm{Bio}}=0.5$ & Ratio of carbon to rest of tree biomass by weight, \\
\hline$\lambda_{\text {oldgrowth } \text { forest }}=0.05 \ldots 0.1 \mathrm{a}^{-1}$ & $\begin{array}{l}\text { biomass decay rate of primeval forest debris } \\
\text { after deforestation (Achard et al., 2002). }\end{array}$ \\
\hline$\lambda_{\text {secndry }}$ forest $=0.05 \mathrm{a}^{-1}$ & $\begin{array}{l}\text { Spin-up time scale for establishment of } \\
\text { secondary forest after deforestation (Schroth, 2002). }\end{array}$ \\
\hline$\lambda_{\text {cultiv }}=1 \mathrm{a}^{-1}$ & $\begin{array}{l}\text { Spin-up time scale for establishment of cultivation } \\
\text { after deforestation. }\end{array}$ \\
\hline$\lambda_{\text {pasture }}=0.5 \mathrm{a}^{-1}$ & $\begin{array}{l}\text { Spin-up time scale for establishment } \\
\text { of pasture after deforestation. }\end{array}$ \\
\hline
\end{tabular}

2000) - if dry and flooded tropical forest would be included, total tropical forest area would be $803 \mathrm{~m} \times 10^{6}$ ha instead; $858 \times 10^{6}$ ha from FRA CS (FAO Forest Resource Assessment, 2000); $780 \times 10^{6}$ ha from FRA RS (FAO Forest Resource Assessment, 2000, remotely sensed values) and $544 \times 10^{6}$ ha from WCMC (World Conservation Monitoring Centre). The first forest area estimate is based on the remote sensing instrument SPOT-VEGETATION (1 km spatial resolution); the second is "based primarily on available information provided and validated by national authorities" (Mayaux et al., 2005), the third estimate is based on "117 multi-date Landsat TM scenes covering approximately $10 \%$ of tropical forest" (Mayaux et al., 2005), with it not yet clear to us exactly what the last estimate is based on. From the four estimates, the first three for all tropical forest are similar, while the fourth estimate is quite different.

We scale the tropical intact forest carbon sink in year $a$, $f(a)$, originally in units of $\mathrm{Mg} \mathrm{DW} \mathrm{ha}^{-1} \mathrm{a}^{-1}$ (DW: Dry
Weight) from Phillips et al. (2009), Fig. 1, to total carbon flux $F\left(\mathrm{Pg} \mathrm{Ca}^{-1}\right)$ using

$F(a)=\left(1+r_{\mathrm{BG}: \mathrm{AGB}}\right) r_{\mathrm{C}: \mathrm{DW}}\left(1-\lambda^{a^{-1970}}\right) A_{0} f(a)$

$r_{\mathrm{C}: \mathrm{DW}} \sim=0.5$ is the ratio of carbon to dry weight of trees, $\mathrm{A}_{0}$ is the area of intact forest in 1970 before intense deforestation started ( $\left.\sim 817 \times 10^{6} \mathrm{ha}\right), \lambda \approx 0.0046$ (i.e. approximately $0.46 \%$ forest area lost per year), estimated from deforestation numbers based on PRODES from 1988 onwards and estimates of Fearnside (2005) from 1970 to 1988 (Table 5). We also assume a belowground to aboveground tree biomass ratio of $r_{\mathrm{BG}} \mathrm{AGB}=0.2$ based on Malhi et al. (2009).

The resulting flux estimates are listed in Table 12 and shown in Fig. 9. The main features are a long-term (19802004) carbon sink of $0.39 \pm 0.26 \mathrm{Pg} \mathrm{Ca}^{-1}$ in the mean (the uncertainty includes the contribution from area estimate variation) with a reduction in the sink from 2005 onwards due to 


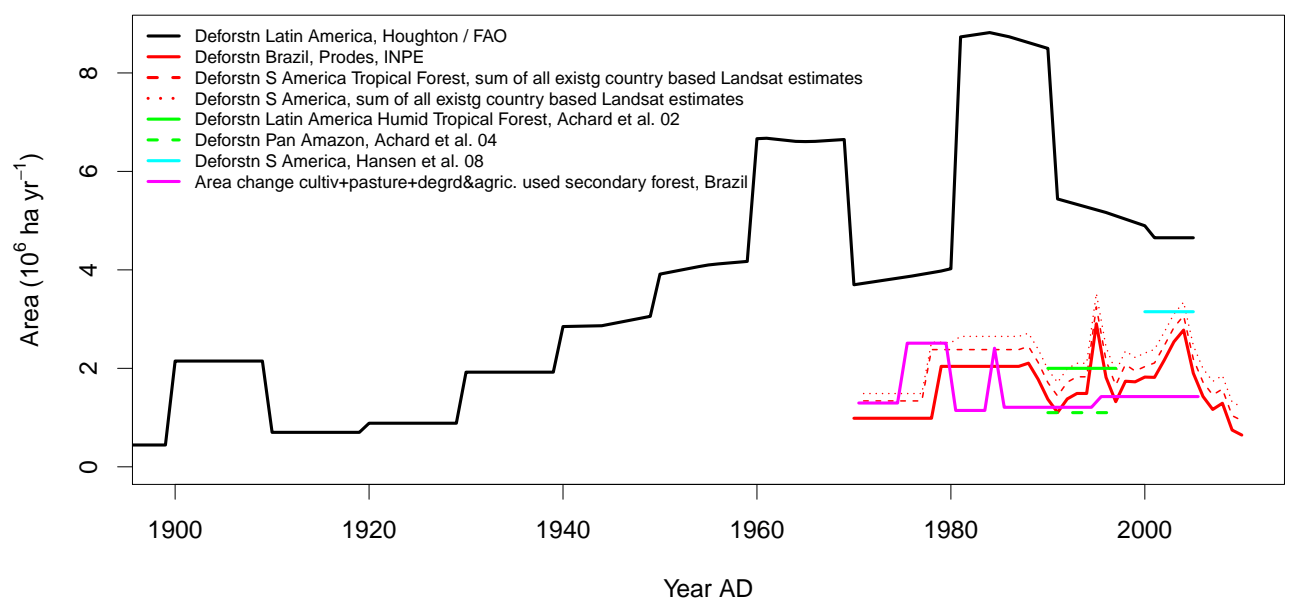

Fig. 7. Comparison of various estimates of annually deforested area in South America, tropical South America, and Brazil, and annual change in agriculturally used land in Brazil based on government statistics (AGROPECUARIA, same as in Fig. 3). The displayed estimates from top down are the following: (i) deforestation rate by area in South America according to FAO statistics (provided by R. Houghton in 2011), (ii) same but just for Brazil and estimated by INPE and Brazil based on Landsat images (PRODES, http://www.obt.inpe.br/prodes), (iii) same, based on PRODES and published studies of deforestation based on remote sensing (mainly Landsat) as listed in Table 4, (iv) same as (iii) but including in addition published remote sensing-based estimates for the rest of South America as listed in Table 4, (v) deforestation rate by area for Latin American humid tropical forests of Achard et al. (2002) based on remote sensing, (vi) same but for South America as estimated by Hansen et al. (2008), and (vii) total change in cultivated area per year due to agriculture in Brazil based on Brazilian government statistics (UNICA, http://www.unica.com.br/dadosCotacao/estatistica).

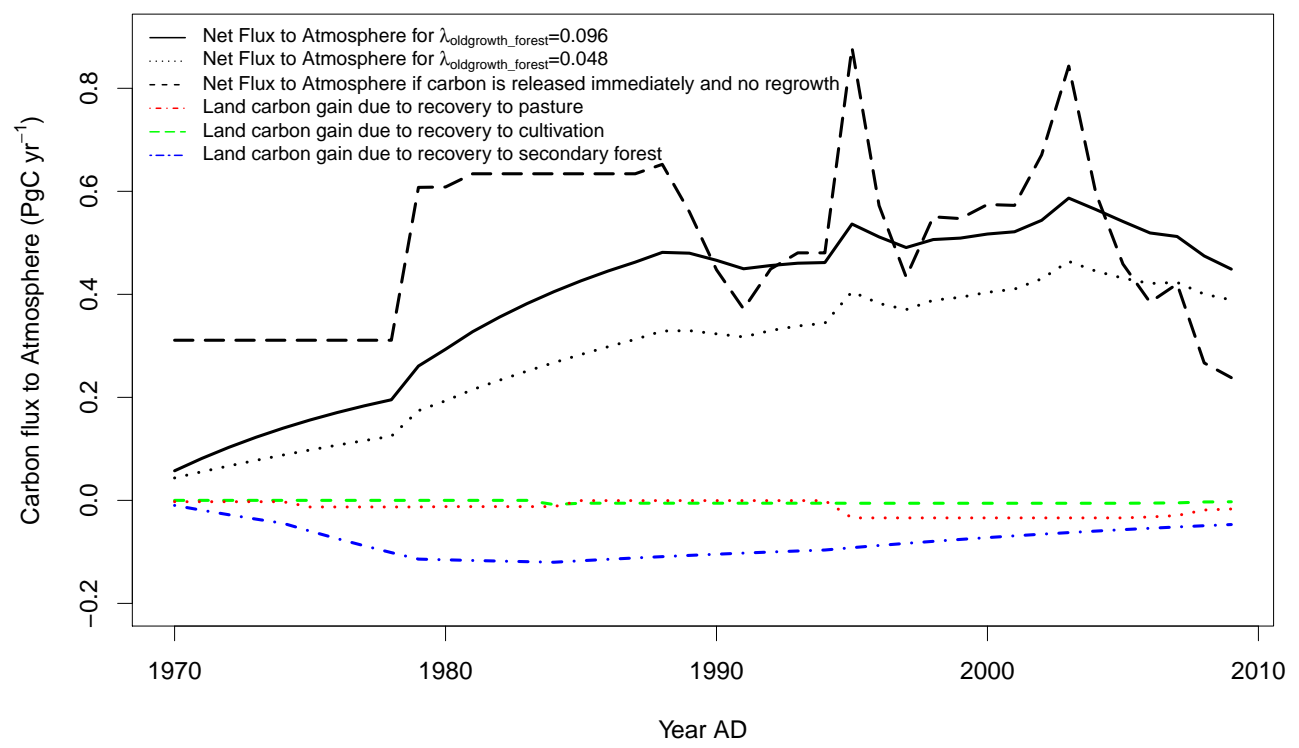

Fig. 8. Estimates of carbon released to the atmosphere from South America due to deforestation for two scenarios: (i) carbon is released gradually and regrowth is taken into account using a simplified book-keeping model following Houghton (1983) as described in Sect. 3.2 and the Appendix, and (ii) all forest carbon after deforestation is released immediately to the atmosphere and there is no regrowth.

the on-going decomposition of dead trees arising as a consequence of unusually high mortality rates due to drought conditions in that year (Phillips et al., 2009). This carbon associated with the drought-associated mortality spike $(\sim 1.2 \mathrm{Pg} \mathrm{C})$ is modelled as not to have been released to the atmosphere immediately, but rather decaying exponentially in time and thus reducing the Amazon Basin forest sink for several years to come. 
Table 7. Summary of published deforestation rates estimated mainly with remote sensing methods.

\begin{tabular}{|c|c|c|c|}
\hline Region & Period & $\begin{array}{l}\text { Deforestation } \\
\text { rate }\left(\mathrm{km}^{2} \mathrm{yr}^{-1}\right)\end{array}$ & Source \\
\hline \multicolumn{4}{|c|}{ Tropical forests } \\
\hline \multirow[t]{2}{*}{ Brazilian Amazon } & 1970-1987 & 15130 & Fearnside (2005) \\
\hline & $1988-2010$ & 16356 & PRODES \\
\hline \multicolumn{4}{|l|}{ Andean Amazon } \\
\hline \multirow{3}{*}{ Bolivia } & 1987-1993 & 1529 & Steininger et al. (2001) \\
\hline & 1990-2000 & 1506 & Killeen et al. (2007b) \\
\hline & 2000-2005 & 2247 & Killeen et al. (2007b) \\
\hline \multirow[t]{2}{*}{ Peru } & $1985-1990$ & 1876 & Perz et al. (2005) \\
\hline & 1999-2005 & 647 & Oliveira et al. (2007) \\
\hline Colombia & \multirow{4}{*}{\multicolumn{3}{|c|}{$\begin{array}{l}\text { no reliable data found } \\
\text { no reliable data found } \\
\text { no reliable data found } \\
\text { no reliable data found }\end{array}$}} \\
\hline Venezuela & & & \\
\hline Ecuador & & & \\
\hline Chile & & & \\
\hline \multicolumn{4}{|c|}{ Extratropical forests (Non-Amazon) } \\
\hline \multirow[t]{2}{*}{ Paraguay } & 1970-1990 & 1394 & Huang et al. (2009) ${ }^{\mathrm{a}}$ \\
\hline & 1990-2000 & 2546 & Huang et al. (2009) \\
\hline \multirow[t]{4}{*}{ Argentina } & 1970-1979 & 103 & Gasparri et al. (2008) \\
\hline & 1980-1989 & 138 & Gasparri et al. (2008) \\
\hline & 1990-1999 & 202 & Gasparri et al. (2008) \\
\hline & 2000-2005 & 208 & Gasparri et al. (2008) \\
\hline
\end{tabular}

${ }^{\mathrm{a}}$ Assuming that the Atlantic forest region is where most forest area is being cleared.

\subsection{Inferences from atmospheric $\mathrm{CO}_{2}$ concentrations and atmospheric transport}

Depending on whether the land is a source or a sink, the effect of a carbon flux between land and the atmosphere is to either increase or deplete the $\mathrm{CO}_{2}$ concentration in the overlying air column. By keeping track of an air parcel's path over a region of interest and by measuring the air column $\mathrm{CO}_{2}$ increase/decrease along the air parcel path, it is thus possible, in principle, to estimate integrated net fluxes along the path. More generally, spatio-temporal concentration patterns in the troposphere contain information on surface fluxes, which theoretically can be extracted by inverting and un-mixing the effect of atmospheric transport and dispersion. This is done in practice using a 3-D atmospheric transport model in an inverse mode. For tropical South America, and the tropics generally, two obstacles do, however, make such an approach currently unreliable.

First and foremost, the troposphere around and inside the continent is highly under-sampled. Inverse methods can potentially provide information from remote observations in the tropical marine boundary layer or in the temperate latitudes. However, both transport modelling shortcomings and the inherent atmospheric dispersion that occurs over transport times of weeks from the tropical land surface to remote sites hamper that approach. As Stephens et al. (2007) showed for the tropics as a whole, tropical land flux estimates derived

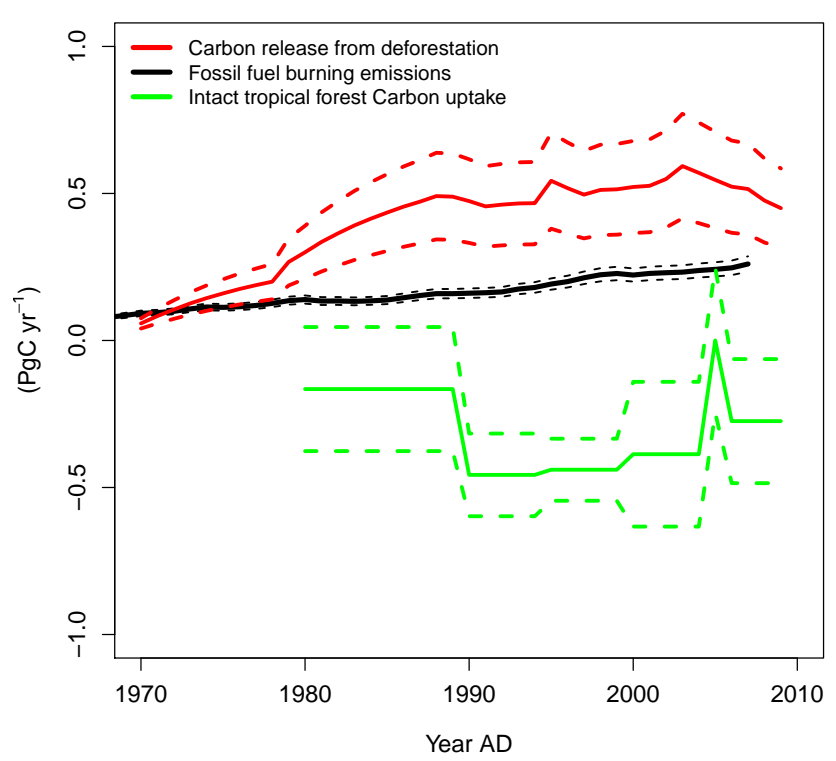

Fig. 9. Flux estimates from South America to the atmosphere (a positive value indicates a flux to the atmosphere) due to deforestation and a simplified book-keeping model, fossil fuel burning and carbon uptake by intact tropical forests.

from $\mathrm{CO}_{2}$ observations at remote sites may reflect biases induced (propagated) by misfits in other regions of the globe.

Second, even with a single inversion model (in which transport is assumed to be perfectly known), the formal 


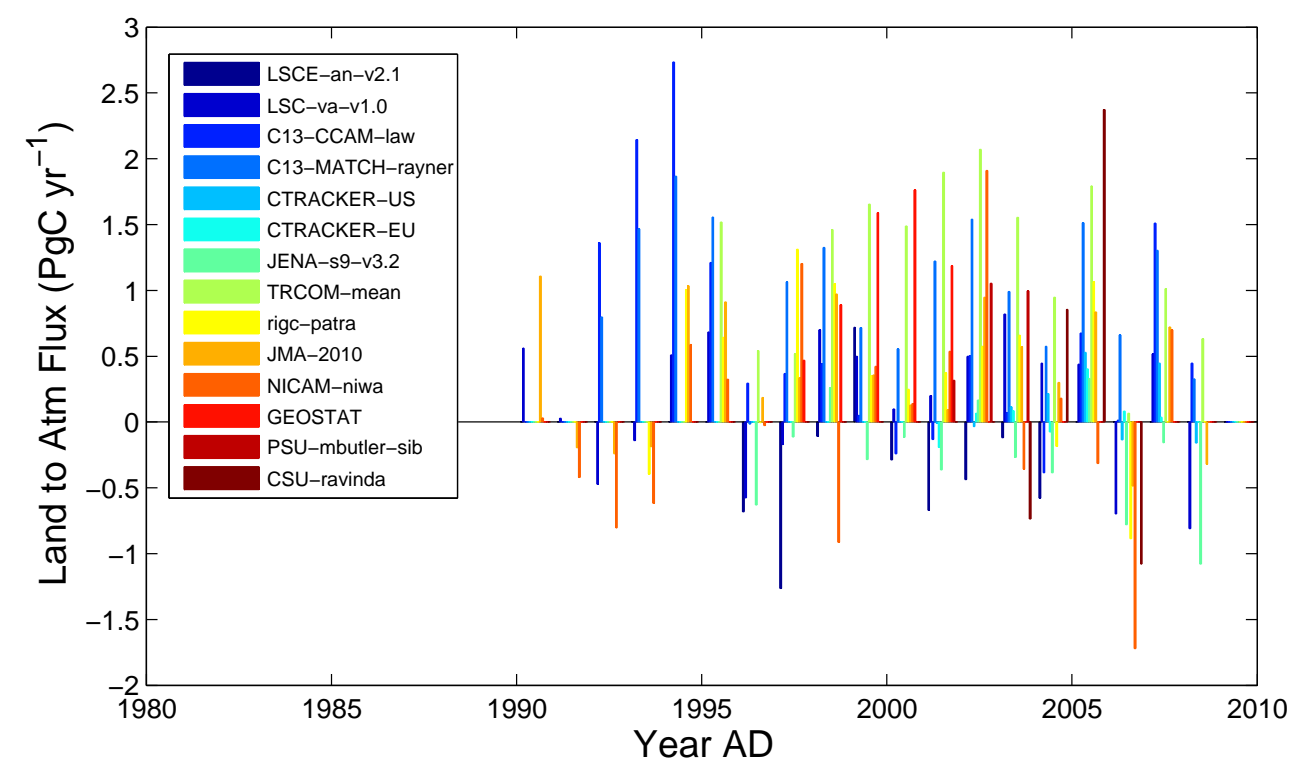

Fig. 10. Net carbon flux estimates from South American land to the atmosphere (i.e. a positive value is a flux to the atmosphere), estimated based on atmospheric $\mathrm{CO}_{2}$ concentration data and inverse modelling of atmospheric transport using a range of specific mathematical inversion techniques prepared especially for RECCAP.

statistical uncertainties are very large, which reflect the loss of information during the transit of air-masses to the remote observation sites. The flux estimates based on classical atmospheric transport inversions in Fig. 10 reveal large scatter in the estimates among models, confirming our assessment of bias. Given that the estimates may largely reflect noise, we conclude their results not to be useful for the purposes of this study.

A new development with atmospheric sampling over South America is that recently joint efforts by IPEN (Sao Paulo, Brazil), NOAA-ESRL (Boulder, USA), University of Leeds (Leeds, UK) and University of Sao Paulo (USP) have led to regular vertical aircraft-based greenhouse gas sampling, with one/two stations (Santarém, Manaus) operating since approximately the year 2000 and four aircraft sites from the end of 2009 onwards. These data should provide the necessary information to allow an atmospheric approach to be successfully applied for the quantification of the carbon sources and sinks associated with both human activity and natural biological processes, integrated across the Amazon Basin. An air parcel back-trajectory-based columnintegration technique applied to the 10-yr record from Santarém reveals a moderate net carbon source of the land region upstream of Santarém, and when fire related fluxes are subtracted on the basis of CO column enhancements, an approximately balanced land surface is found (Gatti et al., 2010). The region upstream of Santarém covers only $10-20 \%$ of the Basin and includes not only forests but also forest converted to agricultural use, as well as savanna and grasslands. It is thus quite likely that the balance of the entire Basin differs from this result.

\subsection{Estimates from dynamic global vegetation models (DGVMs)}

For this study modelling results from five DGVMs have been made available to us (TRENDY project, Sitch, personal communication). The models (DGVMs) were applied globally with common climate forcing and atmospheric $\left[\mathrm{CO}_{2}\right]$ over the historical period 1901-2009 from a combination of ice core and NOAA annual resolution (1901-2009). A 6-hourly, $0.5^{\circ}$ global climate dataset was constructed based on merging the observed monthly mean climatology from the Climate Research Unit (CRU) and NCEP reanalysis. The models were forced over the 1901-2009 period with changing $\left[\mathrm{CO}_{2}\right]$, climate and land use according to the following simulations: varying $\left[\mathrm{CO}_{2}\right]$ only ( $\mathrm{S} 1$ ), varying $\left[\mathrm{CO}_{2}\right]$ and climate (S2), and varying $\left[\mathrm{CO}_{2}\right]$, climate and land use and land cover change (S3, optional). Herein, we present results from simulation S2. The various architectures and processes included by the models are summarised in Table 8 and the flux estimates in Table 11.

The main features of the simulation results of net biome productivity (NBP) (Fig. 11), where NBP is defined as

$N_{\mathrm{B}}=N_{\mathrm{P}}-R_{\mathrm{H}}-F-Q_{\mathrm{R}}$,

where $N_{\mathrm{B}}$ is net biome productivity of land vegetation, $R_{\mathrm{H}}$ heterotrophic respiration of land vegetation, $F$ losses due to fire and $Q_{\mathrm{R}}$ carbon lost by riverine export, are as follows. Inter-annual and decadal variability of the model predictions are similar, nonetheless differences become apparent when fluxes are cumulated over time. With regards to cumulated changes in pool sizes, simulation results can be grouped into 

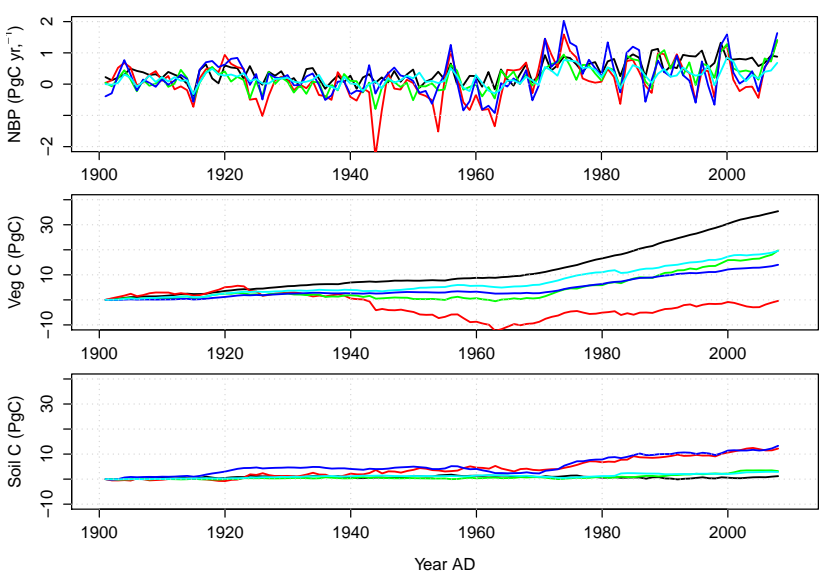

Fig. 11. Dynamic global vegetation model predictions of net carbon flux from the atmosphere to land vegetation (net biome productivity - NBP) for all of South America (a), and cumulative carbon uptake/release by living vegetation (b) and soils (c). NBP is defined as in Eq. (6).

three sets. One model (LPJ) predicts a balanced land vegetation; three models a moderately carbon-gaining vegetation (SDGVM, TRIFFID and OCN); and the last model substantial carbon gains (HYLAND). With the exception of LPJ, all model predictions suggest a regime shift around 1970 towards an increase in carbon gains. Overall, on longer time scales there is substantial divergence in the predictions, indicating that processes relevant to longer term changes may not be properly captured and/or represented by the models at this stage of their development. Thus, we have not included them in the current synthesis.

\subsection{Agricultural and wood production and exports}

For our estimates of carbon fluxes related to deforestation, we have assumed implicitly that all carbon related to agricultural use of originally forested land remains in the country. However, increasingly agricultural products are being exported (Fig. 5). Specifically for Brazil there is a strong trend over the last decade of soybean products and meat from cattle. In terms of carbon the amounts remain small (Tables 9 and 10), and so even with large uncertainties, at present the contribution to the overall carbon budget is negligible. It is worth noting that according to DeFries et al. (2010), trends in deforestation are strongly related to increasing exports (see also Nepstad et al., 2006a).

\subsection{Role of additional components: rivers, volatile organic carbon compounds (VOCs), fire}

For the carbon balance of South America as we have defined it in Sect. 1, riverine carbon discharge to the oceans constitutes a small carbon net loss (i.e. a sink) due to export of dissolved and particulate carbon both from weathering and
Table 8. Exports of wood and wood products.

\begin{tabular}{lcccccc}
\hline \multicolumn{7}{c}{ Processes included in dynamic global vegetation models } \\
\hline DGVM & $\begin{array}{c}\text { Static veg. } \\
\text { composition }\end{array}$ & $\begin{array}{c}\text { Dynamic } \\
\text { vegetation }\end{array}$ & $\begin{array}{c}\text { N- } \\
\text { cycle }\end{array}$ & Fire & $\begin{array}{c}\text { River C } \\
\text { export }\end{array}$ & $\begin{array}{c}\text { Climate } \\
\text { feedback }\end{array}$ \\
\hline Hyland & $\checkmark$ & $\checkmark$ & & & & \\
LPJ & $\checkmark$ & $\checkmark$ & & $\checkmark$ & & \\
SDGVM & $\checkmark$ & & & $\checkmark$ & $\checkmark$ & \\
TRI & $\checkmark$ & $\checkmark$ & & & & $\checkmark$ \\
OCN & $\checkmark$ & & $\checkmark$ & & & $\checkmark$ \\
\hline
\end{tabular}

biomass production. We consider here just the loss of carbon via this route by the Amazon River. Inorganic carbon from weathering is $\sim 0.02 \mathrm{Pg} \mathrm{Ca}^{-1}$ (Probst and Mortatti, 1994) and of organic carbon $\sim 0.05 \mathrm{Pg} \mathrm{Ca}^{-1}$ (Richey et al., 1990). These numbers are small because most organic carbon transported by rivers outgasses within the Basin and thus cancels in a hydrological basin-wide carbon balance.

In addition to $\mathrm{CO}_{2}$, other carbon containing gases, primarily $\mathrm{CH}_{4}$ and $\mathrm{CO}$, contribute to the overall carbon balance of Amazonia in minor ways. $\mathrm{CH}_{4}, \mathrm{CO}$ and volatile organic carbon compounds (VOCs) are all emitted from the terrestrial biosphere. With the carbon within these emitted compounds having to have sometime previously been assimilated into the terrestrial carbon pool through photosynthetic $\mathrm{CO}_{2}$ fixation (with a lag time to their release ranging from seconds to centuries) from the perspective of a carbon balance, these fluxes cancel out. Nonetheless, for completeness we discuss briefly the nature and magnitude of these emissions of carbon in chemically reduced forms. $\mathrm{CH}_{4}$ originates dominantly from anaerobic environments, including permanent wetlands, seasonally flooded forests (e.g. Melack et al., 2004), rumens of buffaloes and cows, and from rice paddies. It is also emitted during the dry season from biomass burning (e.g. van der Werf et al., 2010). While no direct evidence has been found in Amazonia for aerobic plant emissions (Keppler et al., 2006; do Carmo et al., 2006), emissions have been observed from forest canopies, possibly originating form arboreal termites or anaerobic microsites (Patrick Crill, personal communication). Annually averaged emissions for eastern Amazonia, based on atmospheric measurements, which implicitly integrate over all known (and unknown) sources are $\sim 30 \mathrm{mg} \mathrm{CH}_{4} \mathrm{~m}^{-2} \mathrm{~d}^{-1}$, or just $0.02 \mathrm{~g} \mathrm{C} \mathrm{m}^{-2} \mathrm{~d}^{-1}$. In contrast, Gatti et al. (2010) reported net $\mathrm{CO}_{2}$ emissions in the wet season of $0.44 \pm 0.38 \mathrm{~g} \mathrm{C} \mathrm{m}^{-2} \mathrm{~d}^{-1}$ and $0.35 \pm 0.17 \mathrm{~g} \mathrm{C} \mathrm{m}^{-2} \mathrm{~d}^{-1}$ in the dry season. Although total methane fluxes do not have a significant impact on total carbon balance, their radiative forcing contribution is significant because of its roughly 20-fold higher greenhouse gas efficiency (on a mass basis) (Lashof and Ahuja, 1990).

Annual Amazon emissions of CO appear to be dominated by emissions from biomass burning, but there is also a contribution to $\mathrm{CO}$ emissions (evident during the wet season; viz. Fig. 10; Gatti et al., 2010) originating from direct soil emissions (Conrad and Seiler, 1985), direct plant 
Table 9. Export of wood and wood products ${ }^{\mathrm{a}}$.

\begin{tabular}{|c|c|c|c|c|c|c|c|c|c|c|}
\hline & 2001 & 2002 & 2003 & 2004 & 2005 & 2006 & 2007 & 2008 & 2009 & 2010 \\
\hline \multicolumn{11}{|c|}{ Exports in units $\left(10^{3} \mathrm{~m}^{3}\right)$} \\
\hline Argentina & 829 & 1096 & 1496 & 1506 & 1632 & 1649 & 1328 & 1360 & 1278 & 1335 \\
\hline Brasil & 10452 & 11979 & 14084 & 15732 & 22109 & 21133 & 20719 & 19489 & 17828 & 18639 \\
\hline Bolivia & 46 & 46 & 60 & 75 & 88 & 142 & 194 & 109 & 78 & 138 \\
\hline Chile & 8295 & 7086 & 8552 & 9180 & 10504 & 9789 & 11474 & 12231 & 10668 & 10692 \\
\hline Colombia & 172 & 227 & 302 & 316 & 261 & 228 & 280 & 262 & 274 & 313 \\
\hline Ecuador & 300 & 255 & 387 & 395 & 329 & 352 & 433 & 428 & 435 & 416 \\
\hline French Guiana & 6 & 6 & 6 & 6 & 10 & 9 & 9 & 8 & 8 & 8 \\
\hline Guyana & 135 & 128 & 141 & 174 & 192 & 275 & 246 & 174 & 127 & 168 \\
\hline Paraguay & 266 & 316 & 311 & 198 & 250 & 305 & 338 & 370 & 335 & 344 \\
\hline Peru & 137 & 159 & 154 & 194 & 235 & 223 & 230 & 269 & 193 & 207 \\
\hline Suriname & 17 & 35 & 13 & 13 & 15 & 21 & 15 & 38 & 36 & 57 \\
\hline Uruguay & 1030 & 1263 & 1763 & 2635 & 2989 & 3611 & 4136 & 7013 & 6441 & 9335 \\
\hline Venezuela & 95 & 158 & 231 & 264 & 234 & 126 & 154 & 99 & 76 & 91 \\
\hline Total & 21780 & 22754 & 27500 & 30688 & 38848 & 37863 & 39556 & 41850 & 37777 & 41743 \\
\hline \multicolumn{11}{|c|}{ Exports in units $\left(\mathrm{PgC}_{\mathrm{yr}}^{-1}\right)^{\mathrm{b}}$} \\
\hline Total & 0.007 & 0.007 & 0.09 & 0.010 & 0.013 & 0.012 & 0.013 & 0.014 & 0.012 & 0.014 \\
\hline
\end{tabular}

${ }^{\mathrm{a}}$ From FAO statistics.

${ }^{\mathrm{b}}$ From FAO statistics and assuming a wood density of $0.65 \mathrm{t} \mathrm{m}^{-3}$ and a carbon/wood ratio of 0.5 .

Table 10. Exports of Agricultural products ${ }^{\mathrm{a}}$.

\begin{tabular}{lllllll}
\hline Period & Brazil & Argentina & Colombia & Venezuela & Peru & Total \\
\hline \multicolumn{7}{c}{ Meat exports $\left(10^{6} \mathrm{Mg} \mathrm{yr}^{-1}\right)$} \\
\hline $1986-1990$ & 0.45 & 1.00 & 2.70 & 1.75 & 0.90 & 6.80 \\
$1991-1995$ & 0.60 & 1.35 & 3.38 & 1.79 & 0.99 & 8.11 \\
$1996-2000$ & 0.78 & 1.72 & 3.95 & 2.02 & 1.22 & 9.70 \\
$2001-2005$ & 2.56 & 1.91 & 4.41 & 2.35 & 1.29 & 12.5 \\
\hline \multicolumn{7}{c}{ Non-meat agricultural exports $\left(\mathrm{Tg} \mathrm{C} \mathrm{yr}^{-1}\right)$} \\
\hline $1986-1990$ & 7.6 & 0.75 & 1.5 & 0.53 & 0.63 & 11.1 \\
$1991-1995$ & 8.7 & 0.91 & 1.7 & 0.54 & 0.61 & 12.5 \\
$1996-2000$ & 14.0 & 1.1 & 1.7 & 0.53 & 0.91 & 18.2 \\
$2001-2005$ & 24.0 & 1.2 & 1.8 & 0.56 & 0.94 & 28.5 \\
\hline aFrom FAO http///www fao.org/es/ess/top/country html.
\end{tabular}

emissions (Guenther et al., 2006) and via rapid oxidation of isoprene emissions to CO (Kuhn et al., 2007). Gatti et al. (2010) estimated emissions of $27 \mathrm{mg} \mathrm{CO} \mathrm{m}^{-2} \mathrm{~d}^{-1}$ during the wet season, which translates to just $0.01 \mathrm{~g} \mathrm{C} \mathrm{m}^{-2} \mathrm{~d}^{-1}$; clearly a very minor part of the overall carbon balance. Annually averaged $\mathrm{CO}$ emissions including both fire and other processes average roughly $150 \mathrm{mg} \mathrm{CO} \mathrm{m}^{-2} \mathrm{~d}^{-1}$, equivalent to $0.06 \mathrm{mg} \mathrm{C} \mathrm{m}^{-2} \mathrm{~d}^{-1}$. Taken as a whole, $\mathrm{CH}_{4}, \mathrm{CO}$ and VOCs (implicit within the CO totals), appear to contribute less than $0.1 \mathrm{mg} \mathrm{C} \mathrm{m}^{-2} \mathrm{~d}^{-1}$ (i.e. Basin-wide on the order of $2 \times 10^{-3} \mathrm{Pg} \mathrm{Ca}^{-1}$ ) to the overall carbon balance, with $\mathrm{CO}$ from fires most important for carbon balance and $\mathrm{CH}_{4}$ more important for radiative forcing.
Table 11. Exports of wood and wood products.

\begin{tabular}{lrrrrr}
\hline \multicolumn{5}{c}{$\begin{array}{c}\text { Vegetation carbon pool changes estimated with } \\
\text { dynamic global vegetation models' } \\
\text { net biome productivity (NBP) }\left(\mathrm{Pg} \mathrm{C} \mathrm{yr}^{-1}\right)^{\mathrm{a}}\end{array}$} \\
\hline Period & \multicolumn{5}{c}{ Dynamic vegetation model } \\
& Hyland & LPJ & SDGVM & TRI & OCN \\
\hline $1901-1920$ & -0.27 & -0.22 & -0.13 & -0.19 & -0.14 \\
$1921-1940$ & -0.23 & 0.08 & 0.02 & -0.12 & -0.12 \\
$1941-1960$ & -0.19 & 0.34 & 0.1 & 0.03 & -0.1 \\
$1961-1980$ & -0.42 & -0.29 & -0.29 & -0.34 & -0.26 \\
$1981-2000$ & -0.77 & -0.41 & -0.59 & -0.47 & -0.35 \\
$2001-2010$ & -0.78 & -0.26 & -0.60 & -0.47 & -0.39 \\
\hline
\end{tabular}

${ }^{\mathrm{a}} \mathrm{A}$ negative value of NBP corresponds to a flux of carbon to the atmosphere from the land vegetation.

\section{Synthesis}

As policymakers try to determine the best route to mitigation of carbon dioxide release as a consequence of fossil fuel burning, and climate research strives to assess the extent to which the land surface can "draw-down" atmospheric $\mathrm{CO}_{2}$ in to the future, it is becoming increasingly important to understand all components of the global carbon cycle. In particular, detailed regional studies are needed to close the carbon balance. Here we have attempted this for the South American continent.

Although our study is by no means complete, by relying on those data and estimates for which sources are clearly 
Table 12. Summary of carbon flux estimates $\left(\mathrm{PgC} \mathrm{yr}^{-1}\right)$ and carbon balance of South America $\mathrm{a}^{\mathrm{a}}$.

\begin{tabular}{|c|c|c|c|c|c|c|c|}
\hline \multirow[t]{2}{*}{ Process } & \multicolumn{7}{|c|}{ Period } \\
\hline & 1975-1979 & 1980-1984 & 1984-1989 & 1990-1994 & 1995-99 & 2000-2004 & 2005-2009 \\
\hline \multicolumn{8}{|l|}{ Fossil fuel burning } \\
\hline $\begin{array}{l}\text { Deforestation } \\
\text { (a) case: carbon }\end{array}$ & $0.12 \pm 0.012$ & $0.14 \pm 0.014$ & $0.15 \pm 0.015$ & $0.17 \pm 0.017$ & $0.21 \pm 0.021$ & $0.23 \pm 0.023$ & $0.25 \pm 0.025^{\mathrm{b}}$ \\
\hline $\begin{array}{l}\text { released immediately } \\
\text { (b) case: carbon }\end{array}$ & 0.37 & 0.63 & 0.62 & 0.47 & 0.51 & 0.70 & 0.31 \\
\hline $\begin{array}{l}\text { released with time-lags } \\
\text { Old-growth }\end{array}$ & $0.20 \pm 0.05$ & $0.36 \pm 0.09$ & $0.48 \pm 0.12$ & $0.47 \pm 0.12$ & $0.50 \pm 0.12$ & $0.57 \pm 0.14$ & $0.48 \pm 0.12$ \\
\hline forest carbon balance & & $-0.21 \pm 0.23$ & $-0.21 \pm 0.23$ & $-0.57 \pm 0.17$ & $-0.53 \pm 0.14$ & $-0.45 \pm 0.25$ & $-0.15 \pm 0.23^{\mathrm{c}}$ \\
\hline River carbon export & $-0.07 \pm 0.035$ & $-0.07 \pm 0.035$ & $-0.07 \pm 0.035$ & $-0.07 \pm 0.035$ & $-0.07 \pm 0.035$ & $-0.07 \pm 0.035$ & $-0.07 \pm 0.035$ \\
\hline $\begin{array}{l}\text { Export of } \\
\text { agricultural products }\end{array}$ & $0.006^{\mathrm{d}}$ & $0.007^{\mathrm{d}}$ & 0.011 & 0.013 & 0.018 & 0.028 & $0.034^{\mathrm{d}}$ \\
\hline Total & & $0.22 \pm 0.25$ & $0.35 \pm 0.26$ & $0.0 \pm 0.21$ & $0.08 \pm 0.19$ & $0.28 \pm 0.29$ & $\sim 0.51 \pm 0.26$ \\
\hline
\end{tabular}

traceable and for which we have only limited methodological concerns, viz. fossil fuel emissions, estimates of intact forest growth, deforestation and exports of agricultural products, we find that South America was a net source to the atmosphere during the 1980s $\left(\sim 0.3-0.4 \mathrm{Pg} \mathrm{Ca}^{-1}\right)$ and has been close to neutral $\left(\sim 0.1 \mathrm{PgCa}^{-1}\right)$ in the 1990 s with carbon uptake in old-growth forests nearly compensating for carbon losses due to fossil fuel burning and deforestation (Fig. 9; Table 12). The one study employing an atmospheric approach which we have confidence in methodologically is broadly consistent with these results (Gatti et al., 2010).

The situation seems to be changing over the last decade. Although annual mean precipitation over tropical South America (as diagnosed by river discharge) has generally a long-term upward trend, dry seasons have tended to become drier/longer (and thus wet seasons have been wetter). It is currently unclear what the effect of these climate changes on the old-growth forest carbon sink will be. However, first measurements seem to indicate that it may be weakened at least in drought years. Accordingly, the carbon balance of South America may have started turning towards being a weak source to the atmosphere in the 2000s. Finally, the development of the tropical forest regions of the continent is advancing steadily with exports of agricultural products being an important driver of land use change and with exports witnessing a strong upturn over the last decade.

\section{Appendix A}

\section{Simplified Houghton style book-keeping model to estimate carbon release to the atmosphere after defor- estation}

As mentioned in the main text, we assume exponential decay of dead organic material left over after a deforestation event: $\Delta \mathrm{C}=-\lambda \mathrm{C} \Delta t$, where $\mathrm{C}$ is carbon, $\Delta t$ a discrete time interval (one year), and $\lambda_{\text {decmp }}$ a decay constant. Thus, the carbon release during $t-t_{\mathrm{def}}$ years after the deforestation event in year $t_{\mathrm{def}}$ is $F_{\mathrm{ld} \rightarrow \text { at }}\left(t-t_{\mathrm{def}}\right)=\lambda_{\text {decmp }}(1-$ $\left.\lambda_{\text {decmp }}\right)^{t-t_{\text {def }}-1} \mathrm{C}\left(t_{\text {def }}\right)$ with

$$
\mathrm{C}\left(t_{\mathrm{def}}\right)=\underbrace{r_{\mathrm{C}: \mathrm{Bio}} B_{\text {trees }} \Delta A\left(t_{\mathrm{def}}\right)}_{\begin{array}{l}
\text { Total dead biomass due to } \\
\text { clear-cutting of area } \Delta A
\end{array}} \underbrace{(1-\alpha)}_{\begin{array}{l}
\text { fraction of } \\
\text { dead biomass } \\
\text { not immediately } \\
\text { released }
\end{array}}+r_{\mathrm{C}: \mathrm{Bio}} r_{\text {soil release }} \mathrm{C}_{\text {soil }}
$$

where $r_{\mathrm{C}: \mathrm{Bio}}$ is the carbon to mass ratio of wood, $B_{\text {trees }}$ is tree biomass per area $\left(\mathrm{Mgha}^{-1}\right)$, and $\mathrm{C}_{\text {soil }}$ is forest soil organic carbon. The total flux to the atmosphere in year $t$ caused by deforestation during previous years and subsequent decomposition of remaining dead organic material is

$$
F_{\mathrm{ld} \rightarrow \mathrm{at}}^{\mathrm{tot}}(t)=\sum_{t_{\mathrm{def}}=-\infty}^{t} F_{\mathrm{ld} \rightarrow \mathrm{at}}\left(t-t_{\mathrm{def}}\right),
$$

thus

$$
\begin{aligned}
F_{\text {ld } \rightarrow \text { at }}^{\text {tot }}(t) & =r_{\text {C:bio }}\left\{B_{\text {trees }} \alpha \Delta A(t)\right. \\
& +\lambda_{\text {decmp }} \sum_{\text {ndef }=1}^{N-1}\left(B_{\text {trees }}\left(1+r_{\text {bgrd:abgrd }}\right)(1-\alpha) \Delta A\left(t-t_{\text {def }}\right)\right. \\
& \left.\left.+r_{\text {soil release }} \mathrm{C}_{\text {soil }}\right)\left(1-\lambda_{\text {decmp }}\right)^{t-t_{\text {def }}}\right\} .
\end{aligned}
$$

Similarly, as already mentioned as well, the time course of carbon uptake by land due to establishment of a new 
vegetation type after deforestation is assumed to follow $\mathrm{C}\left(t-t_{\text {def }}\right)=\mathrm{C}_{\text {steady }}\left(1-e^{-\lambda_{\text {rgrwth }}\left(t-t_{\text {def }}\right)}\right)$, where $\lambda_{\text {rgrwth }}$ is the inverse of the time scale to establish the new vegetation type. Therefore $F_{\mathrm{ld} \rightarrow \mathrm{at}}\left(t-t_{\mathrm{def}}\right)=r_{\mathrm{C}: b i o} B_{\mathrm{lu}} \Delta A\left(t_{\mathrm{def}}\right)(1-$ $e^{\left.-\lambda_{\mathrm{lu}} t\right)} e^{-\lambda_{\mathrm{lu}}\left(t-t_{\mathrm{def}}\right)}$.

The total flux from the atmosphere to land due to reestablishment of either forest or another vegetation type (we distinguish cultivation, secondary forest and pasture) is then given by $F_{\mathrm{ld} \rightarrow \mathrm{at}}^{\mathrm{tot}}(t)=\sum_{t_{\mathrm{def}}=-\infty}^{t} \sum_{\mathrm{lu}} \alpha_{\mathrm{lu}} F_{\mathrm{ld} \rightarrow \mathrm{at}}\left(t, t_{\mathrm{def}}\right)$, where $F_{\mathrm{ld} \rightarrow \text { at }}\left(t, t_{\mathrm{def}}\right)$ is carbon uptake in year $\mathrm{t}$ in the wake of deforestation in year $t_{\text {def }}$ and is the fraction of originally deforested land being replaced by land use type lu, thus altogether

$F_{\mathrm{ld} \rightarrow \mathrm{at}}^{\mathrm{tot}}(t)=r_{\mathrm{C}: \mathrm{bio}} B_{\mathrm{lu}}\left(1-e^{-\lambda_{\mathrm{lu}} t}\right) \sum_{t_{\mathrm{def}}=1}^{t-1} \Delta A\left(t_{\mathrm{def}}\right) e^{-\lambda_{\mathrm{lu}}\left(t-t_{\mathrm{def}}\right)}$.

The net flux to the atmosphere in year $t$ finally is $F^{\text {net }}(t)=$ $F_{\text {ld } \rightarrow \text { at }}^{\text {tot }}(t)-F_{\text {ld } \rightarrow \text { at }}^{\text {tot }}(t)$. A list of variables and their assigned values to estimate fluxes to and from the atmosphere as a consequence of deforestation and subsequent land use change are given in Table 6 of the main text.

As stressed in the main text, the purpose of the bookkeeping model is to obtain realistic brackets of the fluxes from and to the atmosphere associated with deforestation and land use change based on a model level of complexity matching approximately the level of detail of the available data. The model is centred around the most robust piece of information which is area deforested. Causes of uncertainty in net flux estimates based on this model are due to uncertainty in (i) deforested area - approximately $\pm 10 \%$; (ii) biomass per area - the largest contributor is the uncertainty in primary forest biomass, which based on the RAINFOR plot data we estimate to be in the range of $210-230 \mathrm{tha}^{-1}$; the uncertainty induced is thus approximately $\pm 5 \%$; (iii) fraction of land use after deforestation - since the largest carbon release by far is from brazil and the stocks of pasture and agriculture are small, the error is quite small, on the order of $\pm 5 \%$; (iv) decay and spin-up time scales - the largest influence on the results due to uncertainty in the spin-up time scales is the decay constant of primary forest debris; the uncertainty due to this factor is assessed by doubling the constant and recalculating the fluxes shown in Fig. 8. Altogether we estimate the total uncertainty of our flux estimates to be $\pm 25 \%$.

\section{Supplementary material related to this article is available online at: http://www.biogeosciences.net/9/ 5407/2012/bg-9-5407-2012-supplement.pdf.}

Acknowledgements. We would like to thank Phil Rees, who has advised us on demographic data, the AMAZONICA NERC (NE/F005806/1) and TROBIT consortia grants, and the MOORE foundation, who have supported $\mathrm{MG}, \mathrm{RB}, \mathrm{OP}$, and $\mathrm{TF}$, and L. E. O. C. Aragão acknowledges the support of the UK Natural Environment Research Council (NERC) grants (NE/F015356/2 and NE/1018123/1). We also thank Han Dolman, Pep Canadell and Philippe Ciais for inviting us to participate in the RECCAP effort and to attend the Virginia workshop. Shiela Lloyd assisted with manuscript preparation. We also acknowledge helpful comments from one of the reviewers.

Edited by: P. Ciais

\section{References}

Achard, F., Eva, H. D., Stibig, H.-J., Mayaux, P., Gallego, J., Richards, T., and Malingreau, J.-P.: Determination of deforestation rates of the world's humid tropical forests, Science, 297, 999-1002, doi:10.1126/science.1070656, 2002.

Achard, F., Eva, H. D., Mayaux, P., Stibig, H.-J., and Belward, A.: Improved estimates of net carbon emissions from land cover change in the tropics for the 1990s, Global Biogeochem. Cy., 18, GB2008, doi:10.1029/2003GB002142, 2004.

Aragão, L. E. O. C. and Shimabukuro, Y.: The incidence of fire in Amazonian forests with implications for REDD, Science, 328, 1275-12778, 2010.

Baccini, A., Goetz, S. J., Walker, W. S., Laporte, N. T., Sun, M., Sulla-Menashe, D., Hackler, J., Beck, P. S. A., Dubayah, R., Friedl, M. A., Samanta, S., and Houghton, R. A.: Estimated carbon dioxide emissions from tropical deforestation improved by carbon-density maps, Nat. Geosci., doi:10.1038/NCLIMATE1354, 2012.

Barbosa, R. I. and Fearnside, P. M.: Pasture burning in Amazonia: Dynamics of residual biomass and the storage and release of aboveground carbon, J. Geophys. Res., 101, 25847-25857, 1996.

Birks, H. H. and Birks, H. J. B.: The rise and fall of forests, Science, 305, 484-485, doi:10.1126/science.1101357, 2004.

Boden, T. A., Marland, G., and Andres, R. J.: Global, Regional, and National Fossil-Fuel $\mathrm{CO}_{2}$ Emissions. Carbon Dioxide Information Analysis Center, Oak Ridge National Laboratory, US Department of Energy, Oak Ridge, Tenn., USA, doi:10.3334/CDIAC/00001_V2010, 2011.

Butler, R. A. and Laurance, W. F.: New strategies for conserving tropical forests, Trends Ecol. Evol., 23, 469-472, 2008.

Callède, J., Guyot, J. L., Ronchail, J., L'Hôte, Y., Niel, H., and De Oliveira, E.: Evolution du débit de l'Amazone à Óbidos de 1903 à 1999, Hydrol. Sc. J., 49, 85-97, 2004.

Center for International Earth Science Information Network (CIESIN)/Columbia University, and Centro Internacional de Agricultura Tropical (CIAT): Gridded Population of the World, Version 3 (GPWv3): Subnational Administrative Boundaries. Palisades, NY: NASA Socioeconomic Data and Applications Center (SEDAC), http://sedac.ciesin.columbia.edu/data/ set/gpw-v3, 2005.

Chave, J., Condit, R., Muller-Landau, H. C., Thomas, S. C., Ashton, P. S., Bunyavejchewin, S., Co, L. L., Dattaraja, H. S., Davies, S. J., Esufali, S., Ewango, C.E. N., Feeley, K. J., Foster, R. B., Gunatilleke, N., Gunatilleke, S., Hall, P., Hart, T. B., Hernandez, 
C., Hubbell, S. P., Itoh, A., Kiratiprayoon, S., LaFrankie, J. V., Loo de Lao, S., Makana, J.-R., Supardi Noor, N., Kassim, A. R., Samper, C., Sukumar, R., Suresh, H. S., Tan, S., Thompson, J., Tongco, D. C., Valencia, R., Vallejo, M., Villa, G., Yamakura, T., Zimmerman, J. K., and Losos, E. C.: Assessing evidence for a pervasive alteration in tropical tree communities, Plos Biol., 6, 0455-04642, doi:10.1371/journal.pbio.0060045, 2008.

Conrad, R. and Seiler, W.: Influence of Temperature, Moisture, and Organic Carbon on the Flux of $\mathrm{H}_{2}$ and $\mathrm{CO}$ Between Soil and Atmosphere: Field Studies in Subtropical Regions, J. Geophys. Res., 90, 5699-5709, 1985.

Costa, M. H. and Foley, J. A.: Trends in the hydrologic cycle of the Amazon basin, J. Geophys. Res., 104, 14189-14198, 1999.

Cox, P. M., Betts, R. A., Jones, C. D., Spall, S. A., and Totterdell, I. J.: Acceleration of global warming by carbon cycle feedbacks in a 3-D coupled model. Nature, 408, 184-187, 2000.

Dafonseca, G.: The vanishing Brazilian Atlantic forest, Biol. Cons., 34, 17-34, 1985.

DeFries, R. S., Rudel, T., Uriarte, M., and Hansen, M.: Deforestation driven by urban population growth and agricultural trade in the twenty-first century, Nat. Geosci., 3, 179-181, doi:10.1038/NGEO756, 2010.

do Carmo, J. B., Keller, M., Dias, J. D., de Camargo, P. B., and Crill, P.: A source of methane from upland forests in the Brazilian Amazon, Geophys. Res. Lett., 33, L04809, doi:10.1029/2005GL025436, 2006.

Echeverria, C., Coomes, D., Salas, J., Rey-Benayas, J.-M., Lara, A., and Newton, A.: Rapid deforestation and fragmentation of Chilean Temperate Forests, Biol. Conserv., 130, 481-494, 2006.

Ehleringer, J. R. and Cerling, T. E.: C3 and C4 photosynthesis, in: Encyclopedia of Global Environmental Change, The Earth system: biological and ecological dimensions of global environmental change, 2, 186-190, 2002.

Espinoza Villar, J. C., Guyot, J. L., Ronchail, J., Cochonneau, G., Filizola, N. P., Fraizy, P., Labat, D., De Oliveira, E., Ordoñez Gálvez, J. J., and Vauchel, P.: Contrasting regional discharge evolutions in the Amazon basin (1974-2004), J. Hydrol., 375, 297$311,2009$.

Espinoza Villar, J. C., Ronchail, J., Guyot, J. L., Junquas, C., Vauchel, P., Lavado Casimiro, W. S., Drapeau, G., Pombosa Loza, R.: Climate variability and extreme drought in the upper Solimões River (Western Amazon Basin): understanding the exceptional 2010 drought, Geophys. Res. Lett., 38, L13406, doi:10.1029/2011GL047862, 2011.

Eva, H. D., Belward, A. S., De Miranda, E. E., Di Bella, C. M., Gond, V., Huber, O., Jones, S., Sgrenzaroli, M., and Fritz, S.: A land cover map of South America, Global Change Biol., 10, 731-744, doi:10.1111/j.1529-8817.2003.00774.x, 2004.

Fearnside, P. M.: Deforestation in Brazilian Amazonia: history, rates, and consequences, Conserv. Biol., 19, 680-688, 2005.

Finer, M. and Orta-Martinez, M.: A second hydrocarbon boom threatens the Peruvian Amazon: trends, projections, and policy implications, Env. Res. Lett., 5, 1-10, 2010.

Fisher, J. I., Hurtt, G. C., Quinn, T. R., and Chambers, J.: Clustered disturbances lead to bias in large-scale estimates based on forest sample plots, Ecol. Lett., 11, 554-563, 2008.

Fonseca de Albuquerque Cavalcanti, I., Ferreira, N., Justi da Silva, M., and Faus da Silva Dias, M.: Tempo é Clima no Brasil, Oficina de Textos, São Paulo, Brazil, 2009.
Gasparri, I. N., Ricardo, Grau, H., and Manghi, E.: Carbon pools and emissions from deforestation in extra-tropical forests of northern Argentina between 1900 and 2005, Ecosystems, 11, 1247-1261, 2008.

Gatti, L. V., Miller, J. B., D’Amelio, M. T. S., Martinewski, A., Basso, L. S., Gloor, M. E., Wofsy, S., and Tans, P.: Vertical profiles of $\mathrm{CO}_{2}$ above eastern Amazonia suggest a net carbon flux to the atmosphere and balanced biosphere between 2000 and 2009, Tellus B, 62, 581-594, doi:10.1111/j.1600-0889.2010.00484.x, 2010, 2010.

Gedney, N., Cox, P. M., Betts, R. A., Boucher, O., Huntingford, C., and Stott, P. A.: Detection of a direct carbon dioxide effect in continental river runoff records, Nature, 439, 835-838, doi:10.1038/nature04504, 2006.

Gibbs, H. K., Brown, S., O’Niles, J., and Foley, J. A.: Monitoring and estimating tropical forest carbon stocks: making REDD a reality, Environ. Res. Lett., 2, 13 pp., doi:10.1088/17489326/2/4/045023, 2007.

Gloor, M., Phillips, O., Lloyd, J., Lewis, S. L., Malhi, Y., Baker, T. R., López-Gonzalex, G., Peacock, J., Almeida, S., Alves de Oliveira, A. C., Alvarez, E., Amaral, I., Arroyo, L., Aymard, G., Banki, O., Blanc, L., Bonal, D., Brando, P., Chao, K.-J., Chave, J., Da Vila, N., Erwin, T., Silva, J., Di Fiore, A., Feldpausch, T. R., Freitas, A., Herrera, R., Higuchi, N., Honorio, E., Jiménez, E., Killeen, T., Laurance, W., Mendoza, C., Monteguado, A., Andrade, A., Neill, D., Nepstad, D., Núñez Vargas, P., Peñuelas, M. C., Peña Cruz, A., Prieto, A., Pitman, N., Quesada, C., Salomão, R., Silveira, M., Schwarz, M., Stropp, J., Ramírez, F., Ramírez, H., Rudas, A., Ter Steege, H., Silva, N., Torres, A., Terborgh, J., Vázquez, R., and Van der Heijden, G.: Is the disturbance hypothesis for explaining Amazonian forest growth trends consistent with RAINFOR data?, Global Change Biol., 15, 2418-2430, doi:10.1111/j.1365-2486.2009.01891.x, 2009.

Guenther, A., Karl, T., Harley, P., Wiedinmyer, C., Palmer, P. I., and Geron, C.: Estimates of global terrestrial isoprene emissions using MEGAN (Model of Emissions of Gases and Aerosols from Nature), Atmos. Chem. Phys., 6, 3181-3210, doi:10.5194/acp-63181-2006, 2006.

Hansen, M. C., Stehman, S. V., Potapov, P. V., Loveland, T. R., Townshend, J. R. G., DeFries, R. S., Pittman, K. W., Arunarwati, B., Stolle, F., Steininger, M. K., Carroll, M., and DiMiceli, C.: Humid tropical forest clearing from 2000 to 2005 quantified by using multitemporal and multiresolution remotely sensed data, Proc. Nat. Acad. Sc., 105, 9439-9444, 2008.

Haylock, M. R., Peterson, T. C., Alves, L. M., Ambrizzi, T., Anunciação, Y. M. T., Baez, J., Barros, V. R., Berlato, M. A., Bidegain, M., Coronel, G., Corradi, V., Garcia, V. J., Grimm, A. M., Karoly, D., Marengo, J. A., Marino, M. B., Moncunill, D. F., Nechet, D., Quintana, J., Rebello, E., Rusticucci, M., Santos, J. L., Trebejo, I., and Vincent, L. A.: Trends in total and extreme South American rainfall in 1960-2000 and links with sea surface temperature, J. Clim., 19, 1490-1512, 2006.

Held, I., and Soden, B.: Robust responses of the hydrological cycle to global warming, J. Clim., 19, 5686-5699, 2006.

Hietz, P., Wanek, W., and Dünisch, O.: Long-term trends in cellulose $\mathrm{d}^{13} \mathrm{C}$ and water-use efficiency of tropical Cedrela and Swietenia from Brazil, Tree Physiol. 25, 745-752, 2005.

Houghton, R. A.: Revised estimates of the annual net flux of carbon to the atmosphere from changes in land use and land manage- 
ment 1850-2000, Tellus B, 55, 378-390, 2003.

Houghton, R. A., Hobbie, J. E., Melillo, J. M., Moore, B., Peterson, B. J., Shaver, G. R., and Woodwell, G. M.: Changes in the Carbon Content of Terrestrial Biota and Soils between 1860 and 1980: A Net Release of $\mathrm{CO}_{2}$ to the Atmosphere, Ecol. Mon., 235-262, 1983.

Huang, C., Kim, S., Song, K., Townshend, J. R. G., Davis, P., Altstatt, A., Rodas, O., Yanosky, A., Clay, R., Tucker, C. J., and Musinsky, J.: Assessment of Paraguay's forest cover change using Landsat observations, Glob. Planet Change, 67, 1-12, 2009.

Instituto Brasileiras de Geografia e Estatistica (IBGE): Censo Agropecuário: http://www.ibge.gov.br/home/estatistica/ economia/agropecuaria, 2006.

Jobaggy, E. and Jackson, R.: The vertical distribution of soil organic carbon and its relation to climate and vegetation, Ecol. Appl., 10, 423-436, 2000.

Killeen, T. J.: A perfect storm in the Amazon wilderness, Adv. Appl. Biodivers. Sci., 7, 102 pp., 2007a.

Killeen, T. J., Calderon, V., Soriana, L., Quezada, B., Steininger, M. K., Harper, G., Solorzano, L. A., and Tucker, T. J.: Thirty years of land-cover change in Bolivia: exponential growth and no end in sight, Ambio, 36, 600-606, 2007b.

Lewis, S. L., Lopez-Gonzalez, G., Sonké, B., Affum-Baffoe, K., Baker, T. R., Ojo, L. O., Phillips, O. L., Reitsma, J. M., White, L., James, A., Comiskey, K., Djuikouo, M.-N., Ewango, C. E. N., Feldpausch, T. R., Hamilton, A. C., Gloor, M., Hart, T., Hladik, A., Lloyd, J., Lovett, J. C., Makana, J.-R., Malhi, Y., Mbago, F. M., Ndangalasi, H. J., Peacock, J., Peh, K. S.-H., Sheil, D., Sunderland, T., Swaine, M. D., Taplin, J., Taylor, D., Thomas, S. C., and Wöll, R. V. H.: Increasing carbon storage in intact African tropical forests, Nature, 457, 1003-1006, 2009.

Lloyd, J. and Farquhar, G.: The $\mathrm{CO}_{2}$ dependence of photosynthesis, plant growth responses to elevated atmospheric $\mathrm{CO}_{2}$ concentrations and their interaction with soil nutrient status. I. General principles and forest ecosystems, Funct. Ecol., 10, 4-32, 1996.

Lloyd, J. and Farquhar, G. D.: Effects of rising temperatures and [CO2] on the physiology of tropical forest trees, Phil. Trans. R. Soc Lond. B, 363, 1811-1817, doi:10.1098/rstb.2007.0032, 2008.

Machado, R. B., Ramos Neto, M. B., Pereira, P., Caldas, E., Gonçalves, D., Santos, N., Tabor, K., and Steininger, M.: Estimativas de perda da área do Cerrado brasileiro, Conservation International do Brasil, Brasília, 2004.

Marland, G., Boden, T. A., and Andres, R. J.: Global, Regional, and National Fossil Fuel $\mathrm{CO}_{2}$ Emissions. In Trends: A Compendium of Data on Global Change. Carbon Dioxide Information Analysis Center, Oak Ridge National Laboratory, US Department of Energy, Oak Ridge, Tennesse, USA, 2008.

Malhi, Y.: The carbon balance of tropical forest regions, 19902005, Currrent Opinion in Environmental Sustainability, 2, 237244, 2010.

Malhi, Y. and Wright, J.: Spatial patterns and recent trends in the climate of tropical rainforest regions, Phil. Trans. R. Soc. Lond. B, 359, 311-329 doi:10.1098/rstb.2003.1433, 2004.

Malhi, Y., Phillips, O. L., Lloyd, J., Baker, T., Wright, J., Almeida, S., Arroyo, L., Frederiksen, T., Grace, J., Higuchi, N., Killeen, T., Laurance, W. F., Leaño, C., Lewis, S., Meir, P., Monteagudo, A., Neill, D., Núñez Vargas, P., Panfil, S. N., Patiño, S., Pitman, N., Quesada, C. A., Rudas, A., Salomão, R., Saleska, S., Silva, N.,
Silveira, M., Sombroek, W. G., Valencia, R., Vásquez Martínez, R., Vieira, I. C. G., and Vinceti, B.: An international network to monitor the structure, composition and dynamics of Amazonian forests (RAINFOR), J. Veg. Sc., 13, 439-450, 2002.

Malhi, Y., Wood, D., Baker, T., Wright, J., Phillips, O., Cochrane, T., Meir, P., Chave, J., Almeida, S., Arroyo, L., Higuchi, N., Killeen, T. J., Laurance, S. G., Laurance, W. F., Lewis, S. L., Monteagudo, A., Neill, D., Nunez Vargas, P., Pitman, N., Quesada, C. A., Salomao, R., Silva, J., Torres Lezama, A., Terborgh, J., Vasquez Martinez, R., and Vinceti, B.: The regional variation of aboveground live biomass in old-growth Amazonian forests, Global Change Biol., 12, 1-32, doi:10.1111/j.13652486.2006.01120.x, 2006.

Malhi, Y., Aragão, L. E. O. C., Galbraith, D., Huntingford, C., Fisher, R., Zelazowski, P., Sitch, S., McSweeney, C., and Meir, P.: Exploring the likelihood and mechanism of a climate-changeinduced dieback of the Amazon rainforest, Proc. Nat. Acad. of Sc., 106, 20610, doi:10.1073/pnas.0804619106, 2009.

Marengo, J. and Nobre, C.: Clima da Região Amazônica, in Tempo e Clima no Brasil, edited by: Fonseca de Albuquerque Cavalcanti, I., Ferreira, N., Justi da Silva, M., Faus da Silva Dias, M., Oficina de Textos, 179-212, 2009.

Marimon, B. S., Lima, E. De S., Duarte, T. G., Chieregatto, L. C., and Ratter, J. A.: Observations on the vegetation of northeastern Mato Grosso, Brazil, IV. An analysis of the Cerrado-Amazonian forest, Edinburgh J. Botany, 63, 323-341, doi:10.1017/S0960428606000576, 2006.

Mayle, F. E., Burbridge, R., and Killeen, T. J.: Millennial-Scale Dynamics of Southern Amazonian Rain Forests, Science, 290, 2291-2294, 2000.

Mercado, L. M., Bellouin, N., Sitch, S., Boucher, O., Huntingford, C., Wild, M., and Cox, P. M.: Impact of changes in diffuse radiation on the global land carbon sink, Nature, 458, 1014-1017, doi:10.1038/nature07949, 2009.

Milly, P. C. D., Dunne, K. A., and Vecchia, A. V.: Global pattern of trends in streamflow and water availability in a changing climate, Nature, 438, 347-350, doi:10.1038/nature04312, 2005.

Murty, D., Kirschbaum, M. U., McMurtrie, R. E., and McGilvray, H.: Does the conversion of forest agricultural land change soil carbon and nitrogen?, A review of the literature, Global Change Biol., 8, 105-123, 2002.

Nepstad, D. C., Verissimo, A., Alencar, A., Nobre, C., Lima, E., Lefebvre, P., Schlesinger, P., Potter, C., Moutinho, P., Mendoza, E., Cochrane, M., and Brooks, V.: Large-scale impoverishment of Amazonian forests by logging and fire, Nature, 398, 505-508, 1999.

Nepstad, D., Stickler, C. M., and Almeida, O. T.: Globalization of the Amazon soy and beef industries: opportunities for conservation, Cons. Biol., 20, 1595-1603, 2006a.

Nepstad, D., Schwartzman, S., Bamberger, B., Santilli, M., Ray, D., Schlesinger, P. Lefebvre, P., Alencar, A., Prinz, E., Fiske, G., and Rolla, A.: Inhibition of Amazon Deforestation and Fire by Parks and Indigenous Lands, Cons. Biol., 20, 65-73, 2006 b.

Nobre, C. A., Obregon, G. O., Marengo, J. A., Fu, R., and Poveda, G.: Characteristics of Amazonian Climate: Main Features, in Amazonia and Global Change, edited by: Keller, M., Bustamante, M., Gash, J., Silva Dias, P., Geophys. Mon. Ser., 186, 149-162, 2009. 
Oliveira, P. J. C., Asner, G., Knapp, D. E., Almeyda, A., GalvanGildemeister, R., Keene, S., Raybin, R. F., and Smith, R. C.: Land-use allocation protects the Peruvian, Amazon Science, 317, 1233-1236, 2007.

Oyama, M. D. and Nobre, C. A.: A new climate-vegetation equilibrium state for tropical South America, Geophys. Res. Lett., 30, 2199, doi:10.1029/2003GL018600, 2003.

Poulter, B., Aragao, L., Heyder, U., Gumpenberger, M., Langerwisch, F., Rammig, A., Thonicke, K., and Cramer, W.: Net biome production of the Amazon Basin in the 21st century, Global Change Biol., 16, 2062-2075, 2010.

Perz, S. G., Aramburu, C., and Bremner, J.: Population, Land use and Deforestation in the Pan Amazon Basin: a comparison of Brazil, Bolivia, Colombia, Ecuador, Peru and Venezuela, Env. Dev. Sust., 7, 23-49, doi:10.1007/s10668-003-6977-9, 2005.

Pessenda, L. C. R., Gomes, B. M., Aravena, R., Ribeiro, A. S., Boulet, R., and Gouveia, S. E. M.: The carbon isotope record in soils along a forest-cerrado ecosystem transect: implications for vegetation changes in the Rondonia state, southwestern Brazilian Amazon region, The Holocene, 8.5, 599-603, 1998.

Phillips, O. L., Malhi, Y., Higuchi, N., Laurance, W. F., Nunez, P. V., Vasquez, R. M., Laurance, S. G., Ferreira, L. V., Stern, M., Brown, S., and Grace, J.: Changes in the carbon balance of tropical forests: Evidence from long-term plots, Science, 282, 439442, 1998

Phillips, O. L., Aragão, L. E. O. C., Lewis, S. L., Fisher, J. B., Lloyd, J., López-González, G., Malhi, Y., Monteagudo, A., Peacock, J., Quesada, C. A., Heijden, G. v. d., Almeida, S., Amaral, I., Arroyo, L., Aymard, G., Baker, T. R., Bánki, O., Blanc, L., Bonal, D., Brando, P., Chave, J., Oliveira, Á. C. A. d., Cardozo, N. D., Czimczik, C. I., Feldpausch, T. R., Freitas, M. A., Gloor, E., Higuchi, N., Jiménez, E., Lloyd, G., Meir, P., Mendoza, C., Morel, A., Neill, D. A., Nepstad, D., Patiño, S., Peñuela, M. C., Prieto, A., Ramírez, F., Schwarz, M., Silva, J., Silveira, M., Thomas, A. S., Steege, H. T., Stropp, J., Vásquez, R., Zelazowski, P., Dávila, E. A., Andelman, S., Andrade, A., Chao, K.-J., Erwin, T., Fiore, A. D., C., Honorio, E., Keeling, H., Killeen, T. J., William, F., Cruz, L. A. P., Pitman, N. C. A., Vargas, P. N., Ramírez-Angulo, H., Rudas, A., Salamão, R., Silva, N., Terborgh, J., and Torres-Lezama, A.: Drought sensitivity of the Amazon rainforest, Science, 323, 1344-1347, 2009.

Population Division of the Department of Economic and Social Affairs of the United Nations Secretariat: World Population Prospects: The 2008 Revision, http://esa.un.org/unpp, 2008.

Probst, J. L. and Mortatti, J.: Carbon river fluxes and weathering $\mathrm{CO}_{2}$ consumption in the Congo and Amazon river basins, Appl. Geochem., 9, 1-13, 1994.

PRODES: Brazilian government Deforestation estimates based on remote sensing: http://www.obt.inpe.br/prodes, 2010.

Proyecto Conaf-Conama-Birf, Universidad Austral de Chile, Pontificia Universidad Católica de Chile and Universidad Católica de Temuco. "Catastro y Evaluación de los Recursos Vegetacionales Nativos de Chile." Informe Nacional con Variables Ambientales. Santiago, Chile, 88 pp., 1999.

Quesada, C. A., Lloyd, J., Schwarz, M., Patiño, S., Baker, T. R., Czimczik, C., Fyllas, N. M., Martinelli, L., Nardoto, G. B., Schmerler, J., Santos, A. J. B., Hodnett, M. G., Herrera, R., Luizão, F. J., Arneth, A., Lloyd, G., Dezzeo, N., Hilke, I., Kuhlmann, I., Raessler, M., Brand, W. A., Geilmann, H., Moraes Filho, J. O.,
Carvalho, F. P., Araujo Filho, R. N., Chaves, J. E., Cruz Junior, O. F., Pimentel, T. P., and Paiva, R.: Variations in chemical and physical properties of Amazon forest soils in relation to their genesis, Biogeosciences, 7, 1515-1541, doi:10.5194/bg-7-15152010, 2010.

Quesada, C. A., Lloyd, J., Anderson, L. O., Fyllas, N. M., Schwarz, M., and Czimczik, C. I.: Soils of Amazonia with particular reference to the RAINFOR sites, Biogeosciences, 8, 1415-1440, doi:10.5194/bg-8-1415-2011, 2011.

Quesada, C. A., Phillips, O. L., Schwarz, M., Czimczik, C. I., Baker, T. R., Patiño, S., Fyllas, N. M., Hodnett, M. G., Herrera, R., Almeida, S., Alvarez Dávila, E., Arneth, A., Arroyo, L., Chao, K. J., Dezzeo, N., Erwin, T., di Fiore, A., Higuchi, N., Honorio Coronado, E., Jimenez, E. M., Killeen, T., Lezama, A. T., Lloyd, G., López-González, G., Luizão, F. J., Malhi, Y., Monteagudo, A., Neill, D. A., Núñez Vargas, P., Paiva, R., Peacock, J., Peñuela, M. C., Peña Cruz, A., Pitman, N., Priante Filho, N., Prieto, A., Ramírez, H., Rudas, A., Salomão, R., Santos, A. J. B., Schmerler, J., Silva, N., Silveira, M., Vásquez, R., Vieira, I., Terborgh, J., and Lloyd, J.: Basin-wide variations in Amazon forest structure and function are mediated by both soils and climate, Biogeosciences, 9, 2203-2246, doi:10.5194/bg-9-2203-2012, 2012.

Rao, V. B., Cavalcanti, I. F. A., and Hada, K.: Annual variation of rainfall over Brazil and water vapor characteristics over South America, J. Geophys. Res., 101, 26539-26551, doi:10.1029/96JD01936, 1996.

Regalado, A.: Brazil says rate of deforestation in Amazonia continues to plunge, Science, 329, 1270-1271, 2010.

Richey, J. E., Hedges, J. I., Devol, A. H., Quay, P., Victoria, R., Martinelly, L., and Forsberg, B. R.: Biogeochemistry of carbon in the Amazon River, Limnol. Oceanogr., 35, 352-371, 1990.

Saatchi, S. S., Harris, N. L., Brown, S., Lefsky, L., Mitchard, E. T. A., Salas, W., Zutta, B. R., Buermann, W., Lewis, S. L., Hagen, S., Petrova, S., White, L., Silman, M., and Morel, A.: Benchmark map of forest carbon stocks in tropical regions across three continents, Proc. Nat. Acd. Sc., 108, 9899-9904, doi:10.1073/pnas.1019576108, 2011.

Schroth, G., D'Angelo, S. A., Geraldes Teixeira, W., Haag, D., and Lieberei, R.: Conversion of secondary forest into agroforestry and monoculture plantations in Amazonia: consequences for biomass, litter and soil carbon stocks after 7 years, For. Ecol. Man., 163, 131-150, 2002.

Seibt, U., Rajabi, A., Griffiths, H., and Berry, J. A.: Carbon isotopes and water use efficiency: sense and sensitivity, Oecologia, 155, 441-454, doi:10.1007/s00442-007-0932-7, 2008.

Sierra, R.: Dynamics and patterns of deforestation in the western Amazon: the Napo deforestation front, 1986-1996, Appl. Geogr., 20, 1-16, 2000.

Steininger, M. K., Tucker, C. J., Townshend, J. R. G., Killeen, T. K., Desch, A., Bell, V., and Ersts, P.: Tropical Deforestation in the Bolivian Amazon, Env. Conserv., 28, 127-134, 2001.

Stephens, B. B., Gurney, K. R., Tans, P. P., Sweeney, C., Peters, W., Bruhwiler, L., Ciais, P., Ramonet, M., Bousquet, P., Nakazawa, T., Aoki, S., Machida, T., Inoue, G. Vinnichenko, N., Lloyd, J., Jordan, A., Heimann, M., Shibistova, O., Langenfelds, R. L., Steele, L. P., Francey, R. J., and Denning, A. S.: Weak Northern and Strong Tropical Land Carbon Uptake from Vertical Profiles of Atmospheric $\mathrm{CO}_{2}$, Science, 316, 1732-1735, 2007. 
Soares-Filho, B. S., Nepstad, D. C., Curran, L. M., Coutinho Cerqueira, G. Garcia, R. A., Azevedo Ramos, C., Voll, E., McDonald, A., Lefebvre, P., and Schlesinger, P.: Modelling conservation in the Amazon basin, Nature, 440, 520-523, doi:10.1038/nature04389, 2006.

UNICA: Brazilian government agriculture statistics - unica união da industria de cana-de-acucar, http://www.unica.com.br/ dadosCotacao/estatistica, CANASAT, 2011.

Victoria, R. L., Martinelli, L. A., Moraes, J. M., Ballester, M. V., Krusche, A. V., Pellegrino, G., Almeida, R. M. B., and Richey, J. E.: Surface Air Temperature Variations in the Amazon Region and Its Borders during This Century, J. Clim., 1105-1110, 1998.
White, A., Cannell, M. G. R., and Friend, A. D.: Climate change impacts on ecosystems and the terrestrial carbon sink: a new assessment, Global Environ. Chang., 9, 21-30, 1999.

Williams, E., Dall' Antonia, A., Dall' Antonia, V., de Almeida, J. M., Suarez, F., Liebman, B., and Malhado, A. C. M.: The drought of the century in the Amazon basin: an analysis of the regional variation of rainfall in South America in 1925-26, Acta Amazonica, 35, 231-238, 2005.

Woodward, I.: Stomatal numbers are sensitive to increases in $\mathrm{CO}_{2}$ from pre-industrial levels, Nature, 327, 617-618, 1987.

Yoon, J.-H. and Zeng, N.: An Atlantic influence on Amazon rainfall, Clim. Dyn., 34, 249-264, doi:10.1007/s00382-009-0551-6, 2010. 